\title{
O repensar da educação no Brasil
}

\section{JOSÉ GOLDEMBERG}

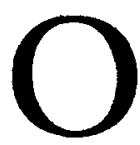

Brasil apresenta, de forma agravada, algumas características próprias de países em desenvolvimento, entre as quais enorme desigualdade na distribuiçáo da renda e imensas deficiências no sistema educacional.

Esses dois problemas estão obviamente associados. Não é possível, hoje em dia, aumentar substancialmente a renda média de adultos sem instruçáo, nem se consegue educar adequadamente crianças cujas famílias vivem à beira da miséria. Por isso mesmo, ao se traçar uma política educacional, há de se evitar a posiçáo simplista de que se pode resolver o problema da pobreza apenas abrindo escolas. Pobreza e ausência de escolarização são deficiências que somente poderáo ser superadas se enfrentadas simultaneamente, cada uma em seu lugar próprio.

O caráter claramente utópico de muitas de nossas políticas educacionais, responsável pelo seu fracasso, se deve, em grande parte, ao fato de não terem sido associadas a uma política social de longo alcance e não estarem alicerçadas em uma clara consciência dos obstáculos econômicos, políticos e culturais que precisam ser enfrentados para a construçáo de um sistema educacional abrangente e de boa qualidade.

Trata-se de tarefa difícil, mas não impossível. É confortador constatar-se que, hoje, no Brasil, a necessidade de garantir uma adequada educaçáo básica ao conjunto da população e de oferecer oportunidades de escolarização posterior a parcela crescente de jovens parece, finalmente, ter deixado de ser apenas afirmação retórica de boas intençôes. $O$ fato, por exemplo, de lideranças, tanto sindicais como empresariais, estarem preocupadas com as deficiências do nosso sistema educacional, revela-se um indicador seguro de que a educação está se constituindo, verdadeiramente, numa prioridade nacional.

Que não tenha sido assim no passado, não pode ser explicado simplesmente pela constataçăo da ausência de vontade política, como se esta pudesse ser constituída independentemente do contexto social. Para entender-se a possibilidade de formação desta vontade, é necessário perguntar em que condiçóes a educaçáo para todos passa a ser vista como 
importante e necessária pela maioria da população e, especialmente, pelas elites econômicas e políticas.

Obviamente, a educaçáo sempre foi considerada um bem em si, pelas oportunidades que oferece de enriquecimento cultural. Mas isso, por si só, não cria as condições para que a universalização do acesso à escola se transforme em prioridade das políticas governamentais. Há duas outras razóes básicas que incentivam políticas públicas no sentido de promover a educação em geral e, especialmente, a escolarização básica.

A primeira delas reside na necessidade de preparação para a cidadania, incorporando à vida nacional grandes massas da populaçăo, dando a elas a instruçáo que lhes permita participar, tanto como eleitores, quanto como usuários dos serviços oferecidos pela sociedade moderna. No mundo todo, a extensão da participaçáo política e do acesso a benefícios sociais, que constituem o cerne da cidadania na sociedade moderna (democrática ou não), esteve associada à universalização da educação básica. Numa sociedade democrática, essa universalização torna-se ainda mais necessária, porquanto dela depende o acesso do eleitorado a informaçóes essenciais para a participação política plena e esclarecida.

A segunda, que se vem manifestando com intensidade crescente, especialmente a partir da Segunda Guerra Mundial, reside na alteração do processo produtivo associada ao desenvolvimento tecnológico, o qual exige mão-de-obra cada vez mais qualificada. Um sistema de educação básica que atenda ao conjunto da populaçáo é hoje essencial ao desenvolvimento econômico.

Se são estas as razóes e condiçōes para constituir uma pontade política que privilegie e valorize a educação, é fácil entender por que, no Brasil, esta vontade é um fenômcno tardio.

Durante todo o século XIX, quando ampliava-se a cidadania e universalizava-se a educação básica nos países desenvolvidos, o Brasil permanecia uma sociedade escravocrata. Fomos o último país ocidental a abolir a escravidáo africana; a extensão da cidadania à maioria da população, constituída por escravos, ex-escravos e seus descendentes, só começou a se colocar como problema real no início deste século.

A pesada herança da escravidão tem conseqüências de longo prazo para a evoluçáo do sistema educacional porque cria problemas específicos para a extensão do acesso à escola. De um lado, pelas mudanças de tradiçóes, valores e hábitos exigidas de uma populaçáo para a qual a 
escola náo faz parte da perspectiva normal de vida nem integra sua tradiçáo cultural. De outro lado, pela resistência das elites tradicionais em estenderem a cidadania a escravos e ex-escravos e, portanto, pela dificuldade em aceitarem e promoverem o ideal da escolarizaçăo universal como fundamento das políticas públicas.

Da perspectiva econômica, a abolição tardia da escravidão está associada à manutençáo de tecnologias primitivas e formas tradicionais de trabalho e dominaçáo, assim como à persistência de uma economia de subsistência em grande parte da zona rural. Para uma populaçáo nessas condiçóes, a escola não é vista como instrumento para a melhoria da situaçăo de vida. Da mesma forma, nas regiōes mais tradicionais do Brasil, na ausência de um processo de industrialização, a escolarizaçáo não constitui exigência para o acesso ao mercado de trabalho urbano nem instrumento de mobilidade social, a náo ser para camadas privilegiadas da população.

Foi apenas no Sul do país que a imigração européia consolidou uma outra tradição, num contexto cultural diverso. Os imigrantes trouxeram consigo uma valorizaçáo da atividade educacional que conseguiu preservar-se e prosperar numa sociedade baseada no trabalho livre e na pequena propriedade. Mesmo no Sul, entretanto, em régióes onde, pelo isolamento, a economia involuiu para uma agricultura' de subsistência, o analfabetismo tendeu a se generalizar. Apesar disso, 'o peso desta outra tradiçáo explica as disparidades na qualidade do sistema educacional que opóem o Norte ao Sul do país. Ainda hoje é no Norte e no Nordeste do país que se concentram os bolsóes de analfabetismo.

Mais recentemente, as migraçóes internas, que levaram milhóes de habitantes das regióes mais pobres e de economia tradicional para os estados mais desenvolvidos do Sudeste e do Sul, sobrecarregaram o sistema educacional destas regióes, pela necessidade de absorver número crescente de crianças cujas famílias não tinham tradição anterior de freqüiência à escola.

Quer no Norte, quer no Sul do Brasil, as dificuldades de universalizar a educaçáo básica foram certamente ampliadas pelo explosivo crescimento populacional que caracterizou o país até muito recentemente. Tal fato implicou a necessidade de uma expansáo acelerada e permanente do sistema escolar, não só para incorporar a populaçáo que antes não tivera acesso à educação formal, como para absorver o número cada vez maior de crianças.

Face a tais dificuldades e impecilhos, há de se reconhecer o esforço 
feito nas últimas décadas para universalizar a educaçāo básica, ao mesmo tempo em que se ampliava o acesso ao ensino médio e superior. Não deve ser subestimado o muito já conseguido no período que sucedeu à Segunda Guerra Mundial, como ocorreu em vários outros países do Terceiro Mundo, os quais perceberam claramente a associaçáo entre educação e desenvolvimento econômico e social.

No Brasil, em 1950, apenas 36,2\% das crianças de 7 a 14 anos tinha acesso à escola. Em 1990, esse índice havia atingido $88 \%$ (1). Como conseqüência desse esforço, a porcentagem de analfabetos na população de mais de 15 anos caiu de $50,6 \%$ para $18,4 \%$ no mesmo período. Além disso, o período de escolarizaçáo obrigatória duplicou, passando de quatro para oito anos. A figura 1 indica o número e o percentual de matrículas nos diferentes níveis de ensino em 1989 e a tabela $\mathbf{l}$ fornece o número de matrículas e o percentual da respectiva faixa etária matriculada nas escolas.

\section{FIGURA 1}

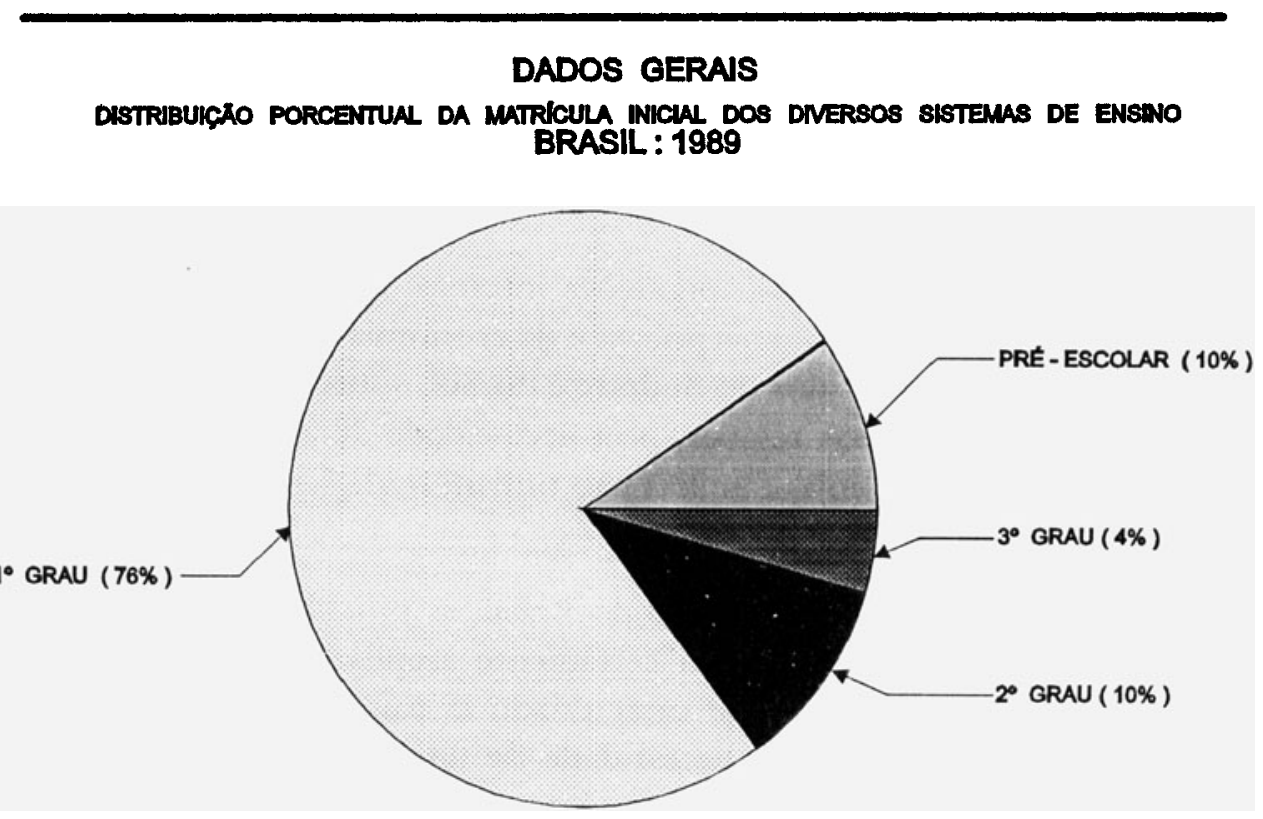

FONTE : MEC - SAG - CPS - CIP 
Matrículas nos Diversos Níveis de Ensino

\begin{tabular}{lrcc}
\hline \multicolumn{1}{c}{ Nível } & \multicolumn{1}{c}{ № } & $\begin{array}{c}\text { \% sobre o total } \\
\text { de matrículas }\end{array}$ & $\begin{array}{c}\text { estimativa \% } \\
\text { faixa etária }\end{array}$ \\
\hline Pré-escolar & 3.396 .074 & 9,4 & 11,42 \\
$1^{\circ}$ grau & 27.557 .492 & 76,6 & $\mathbf{8 2 , 0}(2)$ \\
$2^{\circ}$ grau & 3.477 .859 & 9,7 & 16,5 \\
$3^{\circ}$ grau & 1.528 .904 & 4,2 & 10,0 \\
Total & 39.950 .339 & 100,0 & - \\
\hline
\end{tabular}

Fonte: MEC/SAG/CPS.

Como os dados apresentados indicam (e poderá ser comprovado nas análises mais detalhadas no corpo deste trabalho), os maiores problemas quantitativos do sistema educacional não se situam no acesso à educação básica, ao contrário da percepção comum, que transparece nas críticas mais generalizadas.

As questóes realmente preocupantes referem-se ao reduzido percentual de crianças que conseguem terminar a 8 $8^{\mathrm{a}}$ série, redundando, inclusive, no número relativamente pequeno dos que se matriculam no $2^{\circ}$ grau. O número reduzido de matrículas no $2^{\circ}$ grau constitui um problema grave por se tratar do nível de ensino no qual seria possível oferecer treinamento profissional para a grande parcela de jovens que não têm condiçóes e/ou interesse em fazer um curso superior. A preparaçáo para o trabalho, nesse nível de ensino, poderia contribuir enormemente para a melhoria da qualificaçăo da mão-de-obra e deve constituir uma prioridade da política educacional.

No caso do ensino superior, embora o percentual da faixa etária de 20 a 24 anos matriculada no $3^{\circ}$ grau seja de cerca de $10 \%$ - portanto, muito inferior a de outros países da América Latina, como Argentina (39\%) e Chile (18\%) - , revela-se relativamente elevado quando comparado ao número de estudantes que logra completar o 20. Com efeito, o ingresso no ensino superior representa cerca da metade dos concluintes do ensino médio, considerado muito alto quando se analisa o que ocorre na França, por exemplo, onde tal percentual é de 33\%, conforme dados da Unesco. Desse modo, uma política de expansão do ensino universitário só faz sentido se estiver associada à ampliação do $2^{\circ}$ grau a qual, por sua vez, depende do aumento de concluintes do $1^{\circ}$ grau. 
Os dados também indicam a importância crescente da pré-escola no sistema educacional brasileiro, o que implica a prestaçáo de um serviço relevante, tanto do ponto de vista educacional quanto social, para a população de baixa renda.

Apesar do muito já conseguido, as deficiências do sistema educacional brasileiro constituem certamente um entrave para a modernização da sociedade e precisamos reconhecer que: a qualidade do ensino, tanto público como privado e em todos os níveis é, na maioria dos estabelecimentos, muito deficiente; apesar da quase universalizaçáo do acesso à escola que se logrou atingir, uma porcentagem demasiado pequena dos alunos consegue completar os oito anos de ensino básico obrigatório; o ensino de nível médio não consegue preparar adequadamente os estudantes para a universidade, nem para o ingresso no mundo do trabalho; a formação oferecida nas universidades não promove a qualificação que seria necessária; e a pesquisa é, no mais das vezes, incipiente ou inexistente. Mas a crítica feroz que vem sendo feita ao nosso sistema de ensino, mesmo se justa, não deve nos impedir de reconhecer o muito já feito, e ser sobre esta base que o sistema pode e deve ser melhorado.

\section{A responsabilidade do Poder Público para com a educação}

A legislação brasileira tem, reiteradamente, afirmado a responsabilidade do Poder Público para com a educação, particularmente no que diz respeito ao oferecimento de ensino básico. A última Constituição, inclusive, tornou-o direito público subjetivo (Art. 208, VII, 1²). Que a legislaçáo vem sendo cumprida na medida do possível, pode ser comprovado com números.

Das 27 milhóes e 500 mil crianças matriculadas em escolas de $1^{\circ}$ grau de todo o país (1989), 87,5\% cursavam escolas públicas gratuitas, mantidas com a receita de impostos (tabela 2).

O percentual de atendimento em estabelecimentos públicos, como se comprova, é muito elevado para o $1^{\circ} \mathrm{grau}$, atestando o cumprimento da legislaçáo que obriga o Estado a universalizar, através do ensino público, a escolarização básica.

A oferta relativa de vagas em estabelecimentos públicos na préescola e no $2^{\circ}$ grau também é bastante alta, atingindo cerca de $70 \%$ das matrículas. Apenas no ensino superior a situação se inverte, predominando as matrículas no setor privado. 
Matrícula em estabelecimentos públicos e privados nos diversos níveis de ensino - 1989

\begin{tabular}{|c|c|c|c|c|c|}
\hline \multirow[b]{2}{*}{ Nível } & \multirow{2}{*}{$\begin{array}{c}\mathrm{N}^{2} \mathrm{de} \\
\text { matrículas }\end{array}$} & \multicolumn{2}{|c|}{ Ensino Público } & \multicolumn{2}{|c|}{ Ensino Privado } \\
\hline & & № & $\%$ & № & $\%$ \\
\hline Pré-Escolar & 3.396 .074 & 2.355 .151 & 69,3 & $1,040.074$ & 30,6 \\
\hline $1^{\circ} \mathrm{grau}$ & 27.557.492 & 24.114 .558 & 87,5 & 3.442 .934 & 12,5 \\
\hline $29 \mathrm{grau}$ & 3.477 .859 & 2.421 .390 & 69,6 & 1.056 .469 & 30,4 \\
\hline $3 \%$ grau & 1.518 .904 & 508.980 & 33,6 & $1.009 .924(3)$ & 66,5 \\
\hline
\end{tabular}

Fonte: MEC/SAG/CPS, 1992.

A responsabilidade do Poder Público para com a educaçáo envolve recursos orçamentários vultosos. Em um país como o Brasil, onde a maioria da população situa-se nos limites da pobreza, o direcionamento de recursos do Estado para a área da educaçáo, como a da saúde e as dos demais serviços públicos em geral, náo só é fator essencial para promover os desenvolvimentos econômico e social, como constitui importante instrumento para minorar a excessiva desigualdade na distribuição da renda.

Considerando o montante do Produto Interno Bruto, não é bem verdade que se gaste muito pouco com educaçăo no Brasil. A Constituição Federal determina que, da receita de impostos, a Uniáo aplique pelo menos $18 \%$ em educação e os estados e municípios náo menos de 25\%. De modo geral, tal determinaçáo tem sido respeitada, sendo inclusive responsável pelo aumento dos recursos para a educaçáo ocorrido a partir de 1989. A figura 2 indica os dispêndios efetuados com educaçáo no período entre 1986 e 1990 , atingindo neste último ano o montante de quase 20 bilhóes de dólares.

A figura 3 traduz esses dados em termos de percentuais do PIB. Como pode ser verificado, o percentual mais baixo ocorreu em 1988, quando mal ultrapassou 3\%. Após a vigência da nova Constituiçáo, subiu substancialmente, atingindo, em 1990, 4,21\% do PIB, o que demonstra claramente a importância da vinculação constitucional dos percentuais da receita de impostos para a educaçáo como instrumento para aumentar os investimentos públicos na área.

Para se ter idéia mais clara do que isso representa, podemos fazer uma comparaçáo com outros países, tanto em termos de percentuais do 


\section{DISPENDIOS PÚBLICOS COM O SETOR EDUCAÇÃO}

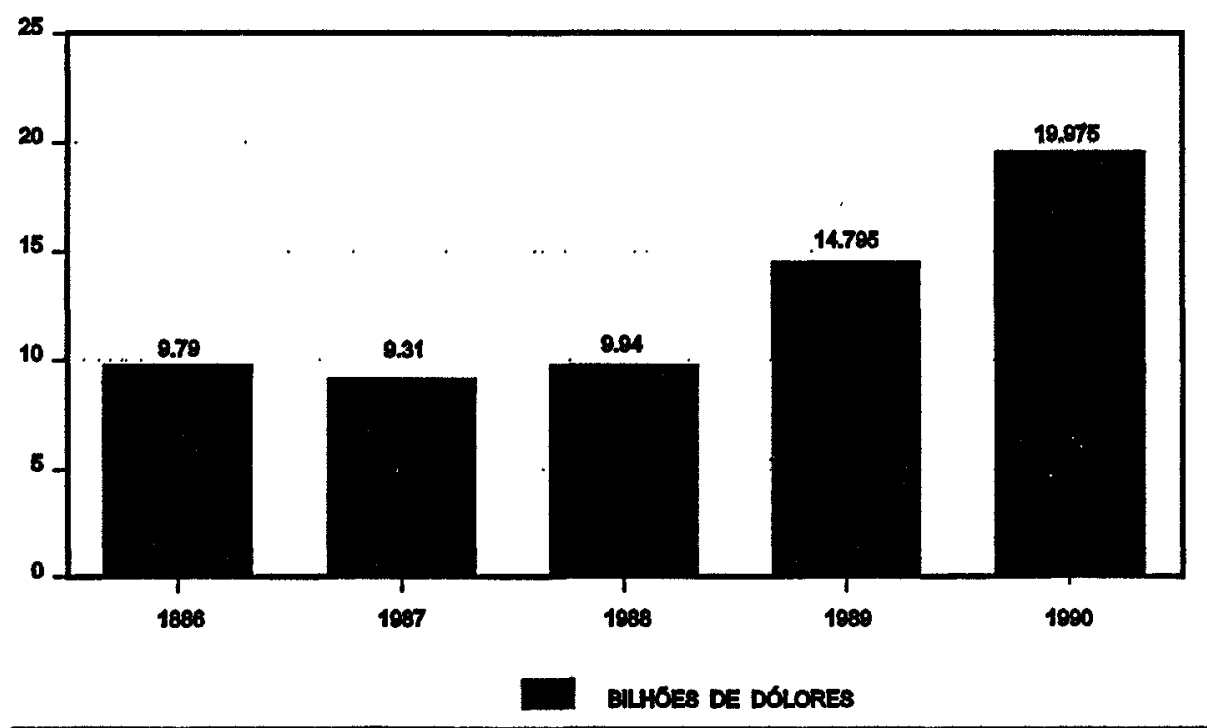

FONTE : MEC - SAG - CPS - 1992

PIB como com relaçáo ao total das despesas públicas. Os últimos dados publicados pela Unesco estão reproduzidos na tabela 3.

Infelizmente, os dados comparativos disponíveis referem-se ao ano de 1988, que foi, no Brasil, justamente aquele de menor investimento relativo na educação desde 1986. Mesmo assim, em termos de percentuais do PIB, o Brasil coloca-se acima de Índia, Espanha e Colômbia (para não falar de Bangladesh), embora abaixo de Vcnezuela, Japão, França e Itália e muito mais de Estados Unidos, Nicarágua e Canadá. A elevação do percentual brasileiro não é, entretanto, tarefa fácil. Como se pode depreender da $2^{a}$ coluna da tabela 3 , o Brasil é dos países que dispende em educação um dos maiores percentuais de suas despesas públicas $(17,7 \%)$, apesar de tais dispêndios representarem apenas $3,7 \%$ do PIB. Isso significa que a prioridade da educaçáo como política governamental está firmemente inserida nos orçamentos públicos; mas, não só o PIB do país é relativamente modesto como o são, mais ainda, as receitas de impostos.

Acresce a este fator negativo o fato do PIB ter-se mantido aproximadamente constante na década 1980/1990, apesar da população esco- 
FIGURA 3

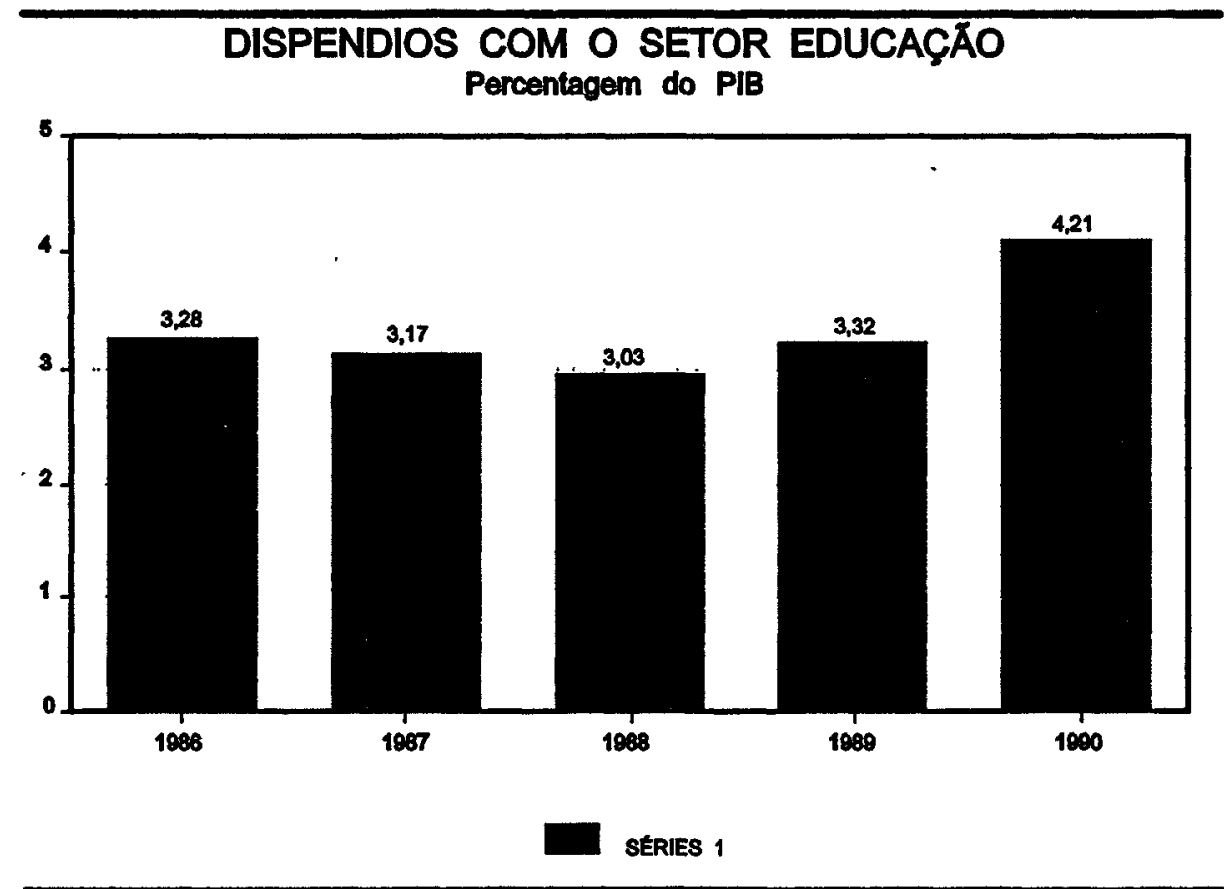

FONTE: MEC - SAG - CPS - 1992

Tabela 3 (4)

Despesas Públicas com Educação - 1988

(com fração do PIB)

\begin{tabular}{|c|c|c|}
\hline País & $\%$ do PIB & $\begin{array}{c}\% \text { das despesas } \\
\text { públicas }\end{array}$ \\
\hline Brasil & 3,7 & 17,7 \\
\hline Colômbia & 2,7 & 22,4 \\
\hline Venezuela & 4,5 & 21,1 \\
\hline Bangladesh & 2,0 & 10,3 \\
\hline Índia & 3,3 & 8,5 \\
\hline Japão & 4,9 & 16,8 \\
\hline Espanha & 3,2 & 13,3 \\
\hline França & 5,4 & 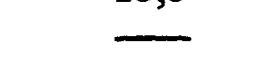 \\
\hline Itália & 5,0 & 8,3 \\
\hline Egito & 5,2 & 10,1 \\
\hline Estados Unidos & 6,8 & - \\
\hline Nicarágua & 6,2 & 12,0 \\
\hline Canadá & 7,1 & 15,6 \\
\hline
\end{tabular}

Fonte: Anuário Estaústico das Naçóes Unidas, 1988. 
lar crescer aproximadamente $2 \%$ ao ano, agravando portanto os problemas das escolas públicas de $1^{\circ}$ e $2^{\circ}$ graus.

Por estas razões, os recursos disponíveis para a educação não são suficientes. Quão insuficientes o são, pode ser ilustrado por outro tipo de cálculo. A figura 4, que discutiremos mais adiante, mostra terem sido os dispêndios dos estados e municípios com educação, em 1989, de 10,7 bilhooes de dólares, destinados essencialmente às escolas de $1^{\circ}$ e $2^{\circ}$ graus. Por outro lado, a contribuiçáo direta da União para com esse nível de ensino é mínima. Dessa forma, se dividirmos aquele montante de recursos pelo número de alunos matriculados nas escolas públicas naquele ano, aproximadamente $\mathbf{3 0}$ milhóes, teremos uma despesa média de $\mathbf{3 5 0}$ dólares por ano, ou, de $\mathbf{3 0}$ dólares por mês, por aluno, valor que representa, grosso modo, o custo relativo do ensino público de $1^{\circ}$ e $2^{\circ}$ graus.

Uma pesquisa realizada no MEC indica que, em 1988, esse custo variou de um mínimo de US\$ 19,8 para escolas municipais de Alagoas a um máximo de US\$ 308 para o Distrito Federal. Números que devem ser comparados com as mensalidades escolares cobradas em escolas particulares típicas; tomando-se uma amostragem de escolas de São Paulo, verifica-se situarem-se essas mensalidades entre 80 e 160 dólares, com valor médio de 120 dólares, isto é, quatro vezes maior do que o dispêndio médio no setor público (tabela 4). Comparando o custo por aluno em escolas públicas e privadas, podemos nos dar conta, portanto, de quão baixo é o dispêndio público por aluno, constituindo, naturalmente, uma das principais causas das dificuldades da educação brasileira.

\section{Tabela 4}

Mensalidade Escolares no Setor Privado

\begin{tabular}{lr}
\hline Nível & US\$/mês \\
\hline Pré-escola & $60-100$ \\
$1^{\text {a a }} 4^{\mathrm{a}}$ série & $80-140$ \\
$5^{\text {a a }} 8^{\mathrm{a}}$ série & $100-160$ \\
$2^{\circ}$ grau & $100-200$ \\
\hline
\end{tabular}

Fonte: MEC-SENEB, 1992

Chegamos assim à situação na qual os dispêndios públicos com educação no Brasil são elevados em termos relativos, mas insuficientes em termos absolutos. 
Ante tal situação de carência, uma posição vem sendo defendida, a de que o Poder Público deveria diminuir os recursos alocados ao ensino superior, o qual atende às camadas mais favorecidas da população, dando prioridade ao ensino fundamental.

No caso do ensino superior, embora o Poder Público tenha uma participaçăo relativa muito menor, em comparaçáo com o que ocorre nos níveis anteriores de ensino, ele é responsável por cerca de um terço do total das matrículas (excluídos os estabelecimentos municipais náo gratuitos) (tabela 5).

\section{Tabela 5}

Matrículas no Ensino Superior - 1990

\begin{tabular}{lcc}
\hline \multicolumn{1}{c}{ Estabelecimentos } & No Matrículas & Matrículas \% \\
\hline Federais e Estaduais gratuitos & $\mathbf{5 2 2 . 4 5 0}$ & 33,4 \\
Municipais não gratuitos & 83.283 & 5,3 \\
Particulares & 959.320 & 61,3 \\
Total & 1.565 .056 & 100,0 \\
\hline
\end{tabular}

Fonte: MEC-SENESu, 1991.

Estima-se que a manutençăo deste sistema público gratuito consuma mais de $20 \%$ dos recursos públicos destinados à educaçáo (náo apenas os orçamentários). Pesquisa realizada no MEC com dados dos Balanços Gerais da Uniáo e dos estados estima que $42,4 \%$ dos gastos da União com educação são destinados ao ensino superior. No conjunto dos estados o percentual é de 15,2\% (tabelas 6 e 7).

Há duas explicaçóes para o envolvimento do setor público com o ensino superior. A primeira, de natureza essencialmente política. A formação de nível universitário beneficia, basicamente, as camadas mais favorecidas da população e as classes médias, as quais têm maior acesso e maior influência junto aos poderes públicos e pressionam fortemente para a manutençáo e expansão do ensino gratuito de $3^{\circ}$ grau.

A segunda diz respeito mais diretamente às necessidades da Naçáo. O desenvolvimento tecnológico que se faz necessário hoje em dia para o estabelecimento de uma economia competitiva exige recursos humanos altamente qualificados. $O$ desenvolvimento econômico pressupóe não só a capacidade de utilizar as tecnologias existentes mas de 
Tabela 6

$$
\begin{gathered}
\text { Brasil - Distribuição Percentual da Despesa da Uniāo } \\
\text { na Função Educação e Cultura, } \\
\text { por Programas Funcionais - } 1988 \text { (5) }
\end{gathered}
$$

\begin{tabular}{lr}
\hline Programas Funcionais & $\%$ \\
\hline Ensino de $1^{\circ}$ grau & 43,8 \\
Ensino de $2^{\circ}$ grau & 6,9 \\
Ensino Superior & 42,4 \\
Ensino Supletivo & 0,1 \\
Educaçáo Física e Desportos &..- \\
Assistência ao Educando & 0,2 \\
Cultura & 1,8 \\
Educaçáo Especial & 0,2 \\
Outros & 4,6 \\
Total & 100,0 \\
\hline
\end{tabular}

Fonte: Balanços Gerais da Uniāo, Estados e DF

\section{Tabela 7}

Brasil - Distribuição Percentual das Despesas das

Unidades da Federação na Função Educação e Cultura, por Programas Funcionais - 1988 (6)

\begin{tabular}{lr}
\hline Programas Funcionais & \multicolumn{1}{c}{$\%$} \\
\hline Ensino de $1^{\circ}$ grau & 56,3 \\
Ensino de $2^{\circ}$ grau & 7,5 \\
Ensino Superior & 15,2 \\
Ensino Supletivo & 0,6 \\
Educaçáo Física e Desportos & 0,9 \\
Assistếncia ao Educando & 1,0 \\
Cultura & 1,9 \\
Educaçáo Especial & 0,2 \\
Outros & 16,4 \\
Total & 100,0 \\
\hline
\end{tabular}

Fonte: Balanços Gerais da União, Estados e DF. 
adaptá-las e de promover inovaçóes. Não basta, para adquirir tal capacidade, a universalização da escolarização básica, embora ela seja indispensável. A formação científica em nível superior é igualmente necessária. Além disso, o processo de desenvolvimento econômico e social exige também pessoal qualificado que possua outras competências, como aquelas necessárias para gerir empresas privadas e serviços públicos. Uma sociedade complexa necessita, ainda, de recursos humanos capazes de elaborar as análises sobre os rumos da economia e as condiçóes de vida, saúde e trabalho da populaçáo; sobre as limitações do sistema educacional $e$ as distorçóes do sistema político; sobre a dinâmica do movimento sindical; sobre fluxos migratórios e o processo de urbanizaçáo; sobre o impacto da transformação socioeconômica no meio ambiente. É por isso que qualquer projeto de modernizaçăo socioeconômica não pode prescindir de universidades capazes de desenvolver a pesquisa científica e formar o pessoal mais qualificado de que a Nação necessita. São esses fatos que justificam a destinação de recursos públicos para a manutenção do ensino superior.

O que pode e deve ser discutido é o montante e o percentual dos recursos públicos destinados a essa finalidade e, inclusive, se a gratuidade é justificada em todos os casos. Tais questóes serão tratadas de forma mais detalhada no decorrer do texto.

\section{O papel diferencial da União, dos estados e dos municipios}

Os dados globais que apresentamos são resultado da atuação das três instâncias do Poder Público: União, estados e municípios, os quais, entretanto, possuem responsabilidades e papéis diversos.

Esta responsabilidade diferencial é traduzida em termos orçamentários. Determina a atual Constituição, no Art. 212, que: "A União aplicará, anualmente, nunca menos de 18, e os estados, o Distrito Federal e os municípios $25 \%$, no mínimo, da receita resultante de impostos, compreendida a proveniente de transferências, na manutenção e desenvolvimento do ensino".

Dada a nossa estrutura tributária, disso resulta que quase a metade dos recursos públicos destinados à educação provêm das aplicaçóes dos estados (tabela 8). 


\section{Tabela 8}

Dispêndios com Educação em 1990

\begin{tabular}{lcc}
\hline Poder & Bilhóes de & \\
Público & dólares & $\%$ \\
\hline Uniáo & 5,2 & 26,1 \\
Estados & 9,0 & 45,2 \\
Municípios & 5,7 & 28,6 \\
Total & 19,9 & 100,0 \\
\hline
\end{tabular}

Fonte: MEC-SAG-CPS, 1992.

A figura 4 apresenta a evolução dos dispêndios com a educação realizados pela Uniáo, estados e municípios a partir de 1986. O que fica claro, neste quadro, é a manutenção da importância central dos estados no desenvolvimento do ensino, paralelamente ao aumento da participação relativa dos municípios a partir da nova Constituição.

FIGURA 4

DISPENDIOS COM O SETOR EDUCAÇÃO

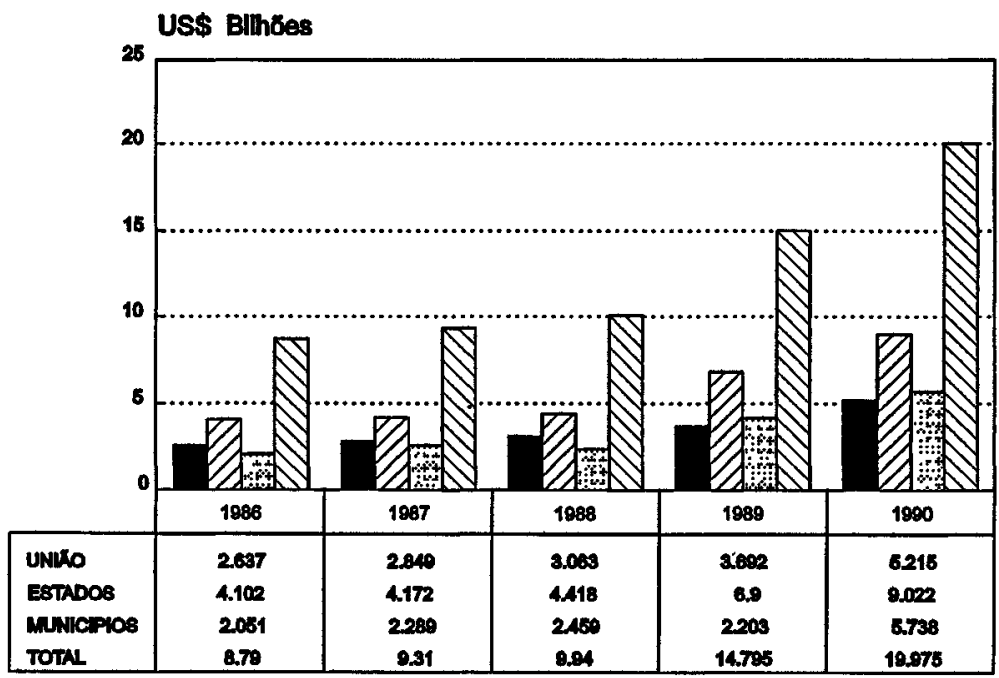

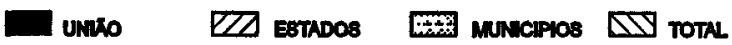

FONTE : MEC - SAG - CPS - 1992 
Isso é devido não só à obrigatoriedade da aplicaçăo dos $25 \%$ da receita de impostos, mas, inclusive, ao aumento da quota dos municípios na distribuição dos recursos globais. Dessa forma, a contribuição municipal, que sempre fora menor se comparada à federal, ultrapassa-a a partir de 1989.

A distribuiçăo diferencial das contribuiçóes financeiras reflete a importância, para o sistema educacional, da atuaçáo dessas instâncias em termos da responsabilidade direta para com o ensino básico.

A tradiçăo brasileira tem sido, efetivamente, a de atribuir a responsabilidade pelo ensino básico aos estados e, secundariamente, aos municípios, reservando à União papel fundamental no que diz respeito ao ensino superior. Dessa forma, sendo a escolarização obrigatória o cerne de todo o sistema de ensino, cabe aos estados e municípios, especialmente ao primeiro, e não à União, o papel central no desenvolvimento da educaçáo nacional.

A força de tal tradição fica claramente expressa na tabela 9, na qual se constata que a União praticamente não atua de forma direta no ensino fundamental, atendendo apenas a $\mathbf{0 , 5 \%}$ dos alunos; os estados sáo os grandes responsáveis por esse nível de ensino, com $57,2 \%$ dos alunos e os municípios atuam complementarmente, absorvendo cerca de $\mathbf{3 0 \%}$ das matrículas.

\section{Tabela 9}

Matrículas em Escolas de 1ㅇ grau em 1989

\begin{tabular}{lrc}
\hline \multicolumn{1}{c}{ Escolas } & Matrículas & $\%$ \\
\hline Federais & 140.983 & 0,5 \\
Escolas Estaduais & 15.755 .120 & 57,2 \\
Escolas Municipais & 828.455 & 29,8 \\
Escolas Particulares & 3.422 .934 & 12,5 \\
Total & 27.557 .492 & $100,0 \%$ \\
\hline
\end{tabular}

Fonte: MEC-SAG-CPS, 1992.

Esta situação origina-se de opçóes realizadas ainda no século passado. Bem antes de se haver constituído um sistema abrangente de ensino, quando as escolas eram poucas, o Ato Adicional de 1834 atribuiu aos municípios a responsabilidade pelo ensino primário, à semelhança da tradiçáo norte-americana e européia. Tratava-se de medida aparente- 
mente progressista, uma vez que entregaria à população local a responsabilidade pela educaçáo das crianças. Mas, numa sociedade escravocrata, de grandes disparidades regionais e sem tradiçáo de controles democráticos sobre os governos locais, o resultado foi o de, praticamente, desobrigar o Poder Público da responsabilidade para com o ensino. Foram os estados que acabaram assumindo a tarefa e, mesmo assim, o índice de analfabetos na população brasileira era, em 1920, de $65 \%$.

A municipalização, todavia, permaneceú como um ideal para muitos educadores. Sua concretizaçáo só será plenamente possível quando diminuírem as excessivas desigualdades regionais e forem ampliados, tanto o interesse da população pela escola, como sua capacidade de avaliar o ensino oferecido e de controlar os orçamentos municipais. Até hoje, apenas dois estados - Paraná e Santa Catarina - lograram alcançar municipalização eficaz, a qual está associada à diversidade da tradição cultural da regiáo Sul do país.

Por outro lado, certamente seria inviável a centralização excessiva, que consistiria em responsabilizar a Uniáo pelo ensino fundamental. $O$ próprio tamanho do país e suas heterogeneidades social e cultural atentam contra a eficácia de uma centralizaçáo desse tipo. O papel da União, no que diz respeito à escolarização básica obrigatória, deve residir, como é hoje, no cumprimento de sua funçáo redistributiva. Uma das prioridades da política educacional deve consistir na institucionalização, em nível federal, de mecanismos eficientes, transparentes e socialmente justos de compensação das desigualdades locais e regionais, ao abrigo de políticas imediatistas ou meramente clientísticas.

Se, em tese, é adequado o princípio estabelecido pela atual legislação, de atribuir tanto aos estados como aos municípios a responsabilidade pela educação básica - pois não se pode prescindir da colaboração de ambos para lograr o atendimento mais amplo e mais eficiente das necessidades educacionais da população - , o sistema se ressente da falta de uma divisão mais clara de responsabilidades entre as duas instâncias.

De acordo com essa legislação, os recursos municipais devem ser destinados à pré-escola e ao $1^{\circ}$ grau, cabendo aos estados atuar no $1^{\circ}$ grau e no nível médio. Ambos são desencorajados a investir em níveis de ensino superiores àqueles determinados como de sua responsabilidade básica, enquanto estes não estiverem plenamente atendidos.

A indefinição resultante da legislação reside na dupla responsabilidade - de estados e municípios - pelo $1^{\circ}$ grau, e tem promovido a constituiçáo de sistemas estaduais e municipais paralelos, sem que haja uma coordenação global. Na prática, o cumprimento da injunçáo consti- 
tucional de obrigatoriedade, por parte do Poder Público, de oferecimento do ensino básico a toda a populaçáo, acaba recaindo sobre os estados. As prefeituras, de fato, têm ampla margem de liberdade no direcionamento de seus recursos, sem necessariamente levar em conta a necessidade de universalizar o acesso ao ensino fundamental. Podem, por exemplo, optar por aumentar o número de pré-escolas, mesmo que haja deficiências graves na extensão da rede de $1^{\circ}$ grau. Ou podem decidir concentrar seus recursos num número reduzido de escolas de $1^{\circ}$ grau de melhor qualidade (inclusive pagando melhor os professores), mesmo quando os recursos do Estado são insuficientes para oferecer o ensino fundamental à maioria da populaçáo que não conseguir ingressar nas escolas municipais. A política estadual fica assim dependente de políticas municipais as mais variadas, cabendo-lhe suprir todas as necessidades que os municípios não podem ou não querem satisfazer. Uma melhor divisão de respónsabilidades entre estas duas instâncias se faz necessária para uma utilização mais eficaz do conjunto de recursos disponíveis para a educação.

Na discussáo da Lei de Diretrizes e Bases da Educaçáo Nacional, o Ministério da Educação defendeu uma proposta neste sentido. Propôs que a responsabilidade pelo ensino fundamental ficasse a cargo dos estados, em colaboraçáo com os municípios, cabendo a cada estado definir a forma de tal colaboração. Desse modo, o estado readquiriria seu papel de coordenador do sistema de ensino, definindo a responsabilidade dos municípios para com a universalização dos oito anos obrigatórios de escolarizaçáo, garantindo a prioridade desse nível de ensino e deixando margem e espaço para uma diferenciação das formas de colaboração, de acordo com as peculiaridades da situaçáo de cada regiāo.

A atribuição da definição das responsabilidades aos estados justifica-se também em funçáo da extrema variabilidade da capacidade e dos recursos municipais e da necessidade de coordenaçáo por uma instância superior.

Na verdade, muitos dos municípios brasileiros são, de fato, extremamente carentes, e outras prioridades, às vezes mais urgentes, consomem praticamente todos os seus recursos. Diversos deles têm como única receita o FPM (Fundo de Participação dos Municípios), cuja existência, aliás, tem encorajado a criaçáo de novos municípios sem condiçóes reais de oferecer os mais elementares serviços à populaçáo.

Por esse motivo, a açáo dos estados, assim como a da União é ainda táo importante e deve ser mantida como, aliás, determina o Art. 212 da Constituiçáo. 
A manutenção do ensino médio, por outro lado, é claramente atribuição da instância estadual, a qual, de fato, é a responsável por $62,4 \%$ do total das matrículas e por $89,6 \%$ das matrículas no setor público (tabela 10).

Tabela 10

Matrículas em Escolas de 2ㅇ grau - 1989

\begin{tabular}{lcr}
\hline Instância & № de matrículas & $\%$ \\
\hline Federal & 97.777 & 2,8 \\
Estadual & 2.170 .632 & 62,4 \\
Municipal & 152.981 & 4,4 \\
Particular & 1.056 .469 & 30,4 \\
Total & 3.477 .859 & 100,0 \\
\hline
\end{tabular}

Fonte: MEC-SAG-CPS, 1992

A União, entretanto, também vem atuando diretamente nesse nível de ensino, embora em escala reduzida, através de uma rede de escolas técnicas e agrotécnicas federais, além de cinco centros de educação tecnológica, os quais oferecem, além da formação em nível médio, também a formação em nível superior. Esta rede de $2^{\circ}$ grau consome cerca de $5,4 \%$ do orçamento do MEC em termos de recursos do Tesouro.

Dado o pequeno desenvolvimento do ensino tecnológico no país, justifica-se a iniciativa da União no sentido de ampliá-lo, especialmente por se tratar de um tipo de formaçăo potencialmente muito importante para a elevaçáo do nível de qualificação da mão-de-obra. Discutível é a questão de saber se a criaçáo de escolas federais mantidas pela União constitui, na verdade, a melhor opçáo para estimular o ensino tecnológico; ou se teria mais sentido uma atuaçáo através do repasse de recursos para os estados. Tal questáo será retomada no decorrer do trabalho.

$\mathrm{Na}$ divisão de responsabilidades pelos diferentes níveis do ensino público, estabelecida pela tradiçáo e pela legislaçăo, cabe prioritariamente à Uniăo a manutenção do ensino superior.

No desempenho dessa atribuição, o Governo Federal criou ampla rede de 54 instituiçóes de ensino superior (IFES), que inclui escolas isoladas e universidades, oferecendo ensino gratuito e integralmente mantidas pelo MEC. O orçamento do MEC reflete tal prioridade, pois 
três quartos dos recursos de que dispóe, provenicntes da receita de impostos, são dedicados a esse nível de ensino.

Entretanto, apesar do vulto dos recursos que o Governo Federal destina à manutenção das IFES, elas atendem a menos de um quarto da populaçáo matriculada no ensino superior (tabela 11).

Tabela 11

Matrículas no Ensino Superior - 1990

\begin{tabular}{lrr}
\hline Instância & \multicolumn{1}{c}{ No } & $\%$ \\
\hline Federal & 320.135 & 20,4 \\
Estadual & 202.315 & 13,0 \\
Municipal & 83.283 & 5,3 \\
Particular & 959.320 & 61,3 \\
Total & 1.565 .056 & 100,0 \\
\hline
\end{tabular}

Fonte: MEC - Sinopse Estatistica do Ensino Superior, 1990.

A incapacidade da União em satisfazer à demanda por ensino universitário é responsável (pelo menos em parte) não só pela ampliaçáo do ensino privado, mas também pelo aumento da rede de universidades públicas estaduais, as quais atendem hoje a $13 \%$ das matrículas.

Os municípios têm também atuado no sentido de criar estabelecimentos de nível superior (geralmente escolas isoladas), apesar de restriçóes da legislação, através de Fundaçóes, as quais operam como instituiçóes de ensino privado (embora criadas por lei municipal) e subsistem, basicamente, através da cobrança de taxas escolares, não onerando de forma significativa o orçamento destinado à educação.

Em termos de ensino superior, o que se verifica, portanto, é a incapacidade da União em atender à expectativa generalizada de satisfazer integralmente à demanda social pela ampliaçáo das universidades públicas, e a necessidade de rever as possibilidades de atuação das diferentes instâncias do Poder Público nesse nível de ensino.

Esse problema tem repercutido, inclusive, sobre a competência normativa e de fiscalizaçáo da Uniáo por abrir a possibilidade do Consetho Federal de Educação transferir, para os estados que mantêm sistemas próprios de ensino superior, a responsabilidade pelo controle da rede privada no seu território. 
As questōes aqui tratadas e as opções existentes estão associadas a problemas gerais, que dizem respeito à centralização e descentralização do sistema. Com referência a esta questáo, entretanto, uma das dimensốes fundamentais relaciona-se à descentralização, que consiste em atribủir maior autonomia $\mathrm{e}$ maior responsabilidade às próprias escolas, problema também a ser retomado no decorrer do trabalho.

\section{O papel e a função do Ministério da Educação no sistema educacional}

O papel fundamental que deve caber ao Ministério da Educaçăo é o de constituir uma instância de formulaçáo da política nacional, de orientaçáo e coordenação dos sistemas de ensino, assim como o de redistribuição de recursos, de forma a compensar as disparidades locais e regionais, em benefício da população como um todo. Associado ao papel redistributivo, cabe-lhe também um papel supletivo, no sentido de atuar em áreas nas quais estados e municípios não encontram condiçóes ou recursos para satisfazer às necessidades do sistema educacional.

O Ministério possui dois instrumentos básicos para cumprir suas funçóes. O primeiro é o orçamento; o segundo, sua competência normativa.

\section{O orgamento}

Como vimos, no conjunto dos recursos públicos destinados à educação, a participação federal é de $26 \%$, portanto bem menor que a dos estados $(45,2 \%)$ e dos municípios $(28,6)$ (Tabela 8 ). Entretanto, ao passo que estes últimos estão dispersos, os recursos federais estáo altamente concentrados em uma única instância decisória, o MEC, e têm, por isso mesmo, um peso muito grande dentro do sistema.

A fonte principal dos recursos federais provém dos $18 \%$ da receita líquida de impostos que, por injunção constitucional, são destinados à educação.

A figura 5 indica a participação relativa do MEC nesses $18 \%$ da receita líquida dos impostos. Como se vê, o Ministério concentra mais de três quartos desses recursos. Mas, conforme pode ser verificado na tabela 12, a alocação dessas verbas pelo Ministério é dirigida, em sua maior parte, para a manutenção das instituiçóes federais de ensino superior. 


\section{MANUTENÇAO E DESENVOLVMENTO DO ENSINO RECURSOS DOS $18 \%$ DOS IMPOSTOS LUUIDOS PARTICIPACAO - 1992}

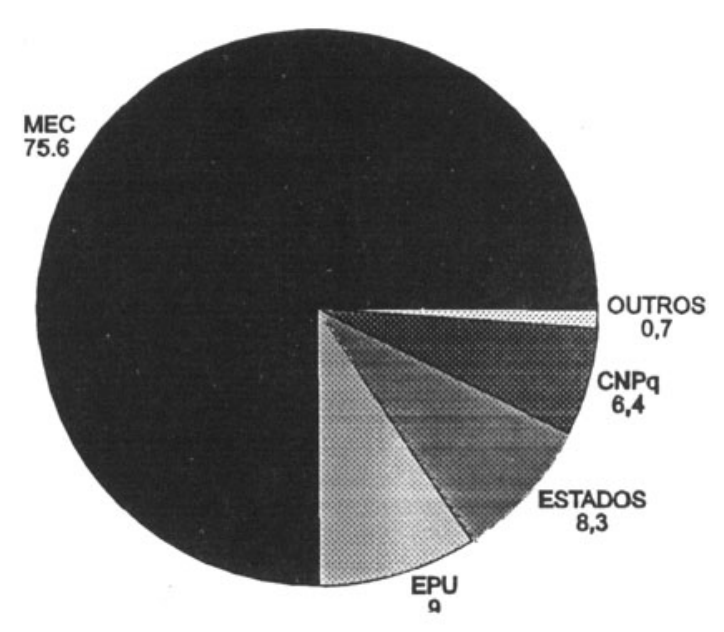

ORÇAMENTO DA UNIXO /92

FONTE:MEC - SAG -CPS - 1992

Tabela 12

Orçamento Executado em 1990 em US\$ milhóes

\begin{tabular}{lrccrr}
\hline Instituição & Pessoal & Custeio & Capital & Total & $\%$ \\
\hline Instituição Federal & & & & & \\
$\quad$ de Ensino Superior & 2.928 & 217 & 166 & 3.312 & 78,4 \\
CAPES & 1 & 131 & - & 132 & 3,1 \\
Escolas Tecnicas & & & & & \\
$\quad$ Federais & 205 & 20 & 6 & 231 & 5,4 \\
Demais Órgãos & 245 & 151 & 153 & 549 & 13,0 \\
Total (7) & 3.370 & 519 & 325 & 4.224 & 100,0 \\
\hline
\end{tabular}

Fonte: MEC-SAG-CPS

O orçamento aprovado em 1992 permite um cálculo mais preciso quanto ao que é possível fazer, com os recursos do Tesouro, em termos de parcelas alocadas aos diferentes níveis de ensino, dada a rigidez das despesas (tabela 13). 


\section{Orçamento Inicial do Ministério da Educação}

(Recursos do Tesouro) 1992

\begin{tabular}{lcc}
\hline Nível & $\begin{array}{c}\text { Milhóes de } \\
\text { dólares }\end{array}$ & $\%$ \\
\hline Ensino Básico & 410 & 10 \\
Ensino Médio & 408 & 10 \\
Ensino Superior & 3.000 & 75 \\
Outros & 163 & 5 \\
Total & 3.981 & 100 \\
\hline
\end{tabular}

Fonte: MEC-SAG-CPS.

A verdade é que, com a responsabilidade pela manutenção das instituiçóes federais de ensino superior, o Ministério náo tem recursos disponíveis para investir nos demais níveis de ensino, a não ser através de incentivos alimentados por outras fontes. Este fato, entretanto, raramente é levado em consideração pelos legisladores e pela população.

O centralismo do período autoritário criou, na populaçáo, a expectativa generalizada de que a União poderia expandir indefinidamente sua capacidade de atendimento às demandas sociais - de que não se tratava de uma questão de estabelecimento de prioridades ante recursos escassos mas, simplesmente, de vontade política. Se houvesse pressão suficiente $\mathrm{e}$ interesse em atender a essas demandas, os recursos surgiriam.

Com a democratização, a reorganização do Estado e a prolongada recessão econômica, a realidade demonstrou ser muito diversa, mas isso não foi ainda inteiramente absorvido pela sociedade. A própria Constituição de 1988 contribui para a permanência de antigas expectativas.

A Constituição foi aprovada em época de euforia pós-regime autoritário, em que tudo parecia possível com a volta da democracia, e apresenta, por isso, um viés assistencialista chegando a assumir, às vezes, caráter utópico. Em virtude dessa ocorrência, ela promoveu grande aumento das responsabilidades da União, especialmente na área da educação, ao mesmo tempo em que foram reduzidos substancialmente seus recursos, não só porque o país ficou mais pobre, mas inclusive por terem sido aumentadas as transferências de receitas para estados e municípios. 
No caso da educaçáo, criou-se, inclusive, situação de inviabilidade, em virtude do artigo 60 das Disposiçóes Transitórias, segundo o qual "nos dez primeiros anos da promulgaçáo da Constituição, o Poder Público desenvolverá esforços, com a mobilização de todos os setores organizados da sociedade e com a aplicação de, pelo menos, $50 \%$ a que se refere o Art. 212 da Constituiçắo, para eliminar o analfabetismo e universalizar o ensino fundamental" . O Art. 212 estabelece, como já se viu, que a Uniăo aplicará nunca menos de $18 \%$ da receita resultante de impostos na manutenção e desenvolvimento do ensino.

A Uniáo aplica esses recursos principalmente através do Ministério da Educaçáo, que gasta mais de $75 \%$ do total do seu orçamento na manutenção das instituiçōes federais de ensino superior. Portanto, para cumprir o artigo 60, o Governo Federal precisaria, ou diminuir drasticamente o que se gasta com as IFES, ou aumentar substancialmente as verbas do Ministério da Educaçáo. A primeira soluçáo é inviável, pois mais de $\mathbf{9 0 \%}$ dos recursos dirigidos para o ensino superior destinam-se ao pagamento de pessoal, o qual, graças à mesma Constituição e às leis que se seguiram, goza de estabilidade e da garantia de irredutibilidade dos salários. Aumentar os recursos do Ministério é também praticamente impossível, devido às demandas de outros setores da área social do Governo, como saúde, transporte e habitação popular, ante os quais a educação já goza de situação privilegiada, por dispor de recursos vinculados.

Os estados, através do Conselho de Secretários de Educaçäo principais interessados nos recursos adicionais da União -, encaminharam uma representação ao Supremo Tribunal Federal para forçar a União a cumprir o disposto no Art. 60 das Disposiçóes Transitórias. $O$ pretendido é a declaração de inconstitucionalidade do orçamento da Uniăo por náo atender ao disposto no Art. 60, com o que concordou o Procurador Geral da República. $O$ assunto ainda não foi resolvido, mas a defesa que o Governo Federal está fazendo passa por duas vertentes diferentes:

- a primeira é que se deve entender por recursos do Poder Público, no Art. 60, a soma dos recursos dos municípios, estados e da Uniáo. Se aceita esta interpretação, não bá dúvida que se gasta em cducação fundamental bem mais de $\mathbf{5 0} \%$ dos recursos totais dedicados à educação. Argumentam alguns, contudo, ser essa uma interpretaçăo falaciosa e que, mesmo se aceita, seria impossível sua fiscalizaçáo, a não ser a posteriori

- a segunda, que os $\mathbf{5 0 \%}$ devem ser computados em termos do conjunto das verbas destinadas ao Ministério da Educaçáo, incluídos, 
além dos $18 \%$ dos impostos da União, recursos suplementares. Isto é o que o Ministério da Economia tem feito quando encaminha ao Congresso Nacional a proposta orçamentária.

Os recursos suplementares vêm de duas fontes: Finsocial, que destina cerca de $7,5 \%$ dos seus recursos para a merenda escolar, e o salárioeducação, suprindo o Fundo Nacional do Desenvolvimento da Educação (FNDE), dois terços dos quais se destinam diretamente aos estados (Quota Estadual) e um terço ao próprio MEC (Quota Federal), que a utiliza para corrigir disparidades regionais. Levando em conta tais recursos, o orçamento total do MEC passa a ser o apresentado na tabela 14.

\section{Tabela 14}

MEC - Orçamento executado em 1990

Todas as fontes em US\$ milhões

\begin{tabular}{lrr}
\hline \multicolumn{1}{c}{ Instituiçóes } & \multicolumn{1}{c}{ Total } & \multicolumn{1}{c}{$\%$} \\
\hline Instituiçóes Federal de Ensino Superior & 3.312 & 53,0 \\
Salário Educação repassado para o Estado & 926 & 14,6 \\
FAE & 616 & 9,8 \\
FNDE & 480 & 7,7 \\
CAPES & 132 & 2,1 \\
Escolas Técnicas Federais & 231 & 3,6 \\
Demais Órgãos & 549 & 8,8 \\
Total & 6.247 & 100,0 \\
\hline
\end{tabular}

Fonte: MEC-SAG, 1991.

A verdade é que, face a encargos que lhe foram atribuídos por lei, por iniciativa do próprio Congresso, e consagrados na Constituição, o MEC náo tem como, simultaneamente, atender ao Art. 112, na sua interpretação estrita, e manter as universidades federais, contando apenas com a sua participaçáo na receita de impostos. Aliás, em virtude da sua responsabilidade para com o ensino superior, a atuaçáo do MEC nos demais níveis de ensino está quase que totalmente na dependência dos recursos suplementares e esta realidade precisa ser reconhecida. 
O orçamento constitui o instrumento mais eficaz de atuação política do Ministério. É através da distribuição criteriosa dos recursos que o MEC pode cumprir suas funçóes supletivas, redistributivas e, inclusive, as de coordenação do sistema. Para esta última finalidade conta, entretanto, com outros instrumentos, que derivam de suas atribuiçóes normativas e se consubstanciam em decretos, instruçóes, projetos de lei enviados ao Congresso Nacional e regulamentaçôes burocráticas em geral. O Conselho Federal de Educação é o principal organismo de regulamentaçáo. Relativamente aos $1^{\circ}$ e $2^{\circ}$ graus, o instrumento fundamental do Conselho é o estabelecimento do currículo mínimo, que deve garantir uma base uniforme na formação escolar em todo o território nacional. No ensino superior, além do currículo mínimo, o Conselho conta ainda com o poder do credenciamento das instituiçóes e o reconhecimento dos cursos. No caso de instituiçóes de ensino que não são universidades, depende do Conselho, inclusive, a fixação do número de vagas.

Ao longo dos anos e em função da nossa própria tradição burocrática, tal instrumento normativo assumiu desmesurada importância, em detrimento de outros, mais ágeis e mais eficazes. Criou-se, tanto $\mathrm{em}$ nível federal como estadual, uma grande burocracia cuja primordial função é verificar o cumprimento das normas. Os defeitos de um sistema desse tipo sáo múltiplos. De um lado, privilegia uma forma de atuação do Estado que consiste em verificar a observância dos aspectos legais e formais, em detrimento de avaliaçáo dos problemas e do desempenho do sistema de ensino, estímulo a soluçóes inovadoras, coordenação de esforços. De outro, torna todo o sistema extremamente rígido, cxatamente pela multiplicação e crescente detalhamento das normas. Além disso, num sistema como esse, que multiplica normas universais, válidas para todo o sistema, é impossível a adequação de soluçóes às peculiaridades regionais, locais e mesmo de cada bairro e de cada escola. Ambos os problemas ficam muito claros na questão do currículo mínimo, que tende a uma ampliaçẫo constante a ponto de nāo deixar margem para a flexibilidade necessária, assegurada em princípio. Finalmente, a multiplicação de controles burocráticos estimula excessiva concentraçăo de recursos e pessoal nos órgãos de administraçáo e fiscalização, em detrimento daqueles que exercem atividades-fim.

A modernização desse sistema, necessária para aumento da eficiência e melhor aplicação dos recursos públicos, deve passar por uma drástica redução do aparato normativo em benefício de outros instrumentos de orientaçáo e coordenaçáo, associados à aplicaçáo dos recursos financeiros disponíveis. Implica planejar o orçamento de forma a canalizar auxílios financeiros para a solução de problemas claramente defi- 
nidos nos diferentes sistemas e níveis de ensino, através de critérios transparentes e objetivos.

O uso do estímulo, em vez de normas, contribuiria enormemente para agilizar todo o sistema de ensino, privilegiando novas iniciativas, corrigindo distorçóes, exigindo a análise permanente dos problemas a serem enfrentados e das prioridades a serem estabelecidas.

Modernização deste tipo começou a tomar forma no Ministério da Educação, através de duas séries de iniciativas. Uma, interna, consistiu na reorganização do sistema de distribuição de auxílios. No caso do ensino básico, que certamente é a grande prioridade educacional, esta reorganizaçáo concentrou-se, particularmente, no FNDE e na FAE. A outra iniciativa, externa, consistiu num diálogo permanente com o Congresso Nacional, no sentido de promover a simplificação da legislaçáo existente, evitando o detalhismo excessivo que constitui uma deformação básica do sistema normativo. A discussão da Lei de Diretrizes Básicas, ainda em curso, é elemento fundamental dessa estratégia, que deve incluir a redução dos poderes do CFE, a reformulação de sua composição e de sua área de competência, diminuindo as funçōes normativas e favorecendo sua atuação como órgão consultivo para formulação de políticas educacionais.

Outro problema a ser enfrentado para a modernização da ação do Estado diz respeito à forma pela qual a União exerce sua funçáo supletiva. Dadas as carências do nosso sistema educacional, deve realmente caber à União uma atuação em aspectos ou setores relevantes do sistema educacional não cobertos satisfatoriamente pela iniciativa e com os recursos municipais e estaduais.

A atuação direta do MEC na área do ensino superior, por exemplo, tem este caráter supletivo, e justifica-se plenamente em virtude da necessidade de canalizar recursos dos estados e municípios para a soluçáo dos problemas do ensino básico. Foi em virtude também de uma atuação supletiva semelhante que o MEC passou a atuar na área de educação tecnológica de $2^{\circ}$ grau. O problema reside no fato de tal atuação ter sido muito mais orientada no sentido de criar uma rede de escolas federais do que de incentivar, apoiar e financiar iniciativas estaduais.

Assim, são criadas duas dificuldades. Em primeiro lugar, o peso da administraçáo de uma rede de estabelecimentos federais, cobrindo todo o território nacional, concentra atençáo e esforços do MEC. Em vez de caracterizar-se como instância de coordenação política e redistribuição de recursos, o MEC passa a administrar um sistema próprio, paralelo aos sistemas estaduais e municipais e, às vezes, em competição 
com eles. Além disso, sendo responsável por uma rede de estabelecimentos próprios e cobrindo privilegiadamente dois níveis do sistema de ensino (o superior e o técnico), o MEC concentra sobre si todas as pressóes municipais e estaduais para a expansão da rede, quando devia orientá-las no sentido de suscitar iniciativas locais. Dessa forma, a possibilidade de atuar nos demais níveis fica seriamente prejudicada, pois sua rede própria concentra todas as pressóes e consome todos os recursos e todos os esforços.

A descentralização do sistema deveria ser contemplada a médio c longo prazo. Ante as imensas dificuldades políticas envolvidas e os prejuízos para o sistema de ensino que poderiam resultar de um desmantelamento da rede federal existente ou da sua estadualizaçáo forçada, uma orientação desse tipo deve ser gradual, contemplando a expansăo do sistema atual, mais do que as instituiçóes já sob a administração do MEC.

\section{A educação básica}

\section{Analfabetismo e acesso à escola}

No Brasil, até recentemente, a preocupação com o analfabetismo foi maior do que a com o ensino básico. Periodicamente a imprensa anunciava (como o faz ainda hoje) índices alarmantes de analfabetos, induzindo a campanhas de alfabetização, dirigidas basicamente aos adultos que não sabiam ler nem escrever.

Campanhas desse tipo raramente produzem resultados satisfatórios, porque são orientadas no sentido de combater os efeitos da falta de acesso à escola e não a sua causa. $O$ modo de erradicar o analfabetismo é a garantia da universalização do ensino fundamental público e gratuito, o que vem sendo feito ultimamente. Em termos de analfabetismo, está em andamento no Brasil uma revolução silenciosa.

Malgrado o que dizem as Cassandras sobre os problemas da educação no país, os números frios do recenseamento do IBGE mostram que a taxa de escolarizaçăo, isto é, o acesso das crianças de 7 a 14 anos à escola, praticamente universalizou-se $\mathrm{e}, \mathrm{com}$ isso, menor é o número delas que chega à idade adulta analfabeta. 
É importante comprovar tal afirmação com dados. A figura 6 indica a evolução da taxa de analfabetismo no Brasil. Tendo-se mantido estável em torno de $65 \%$ nos dois primeiros decênios deste século, começou a declinar a partir de 1920 e, de forma acelerada, depois da Segunda Guerra Mundial, para atingir, em 1990, pouco menos de $18,5 \%$ da população, altamente concentrados nas faixas etárias acima de 40 anos. O analfabetismo tende, portanto, a desaparecer. A maioria da população analfabeta de hoje, com mais de 40 anos, deveria ter ido à escola na década de 50 . Mas, à época, apenas $38 \%$ das crianças de 7 a 14 anos estavam matriculadas nos estabelecimentos de ensino - toda a população escolar era de apenas 3,8 milhóes de crianças.

FIGURA 6

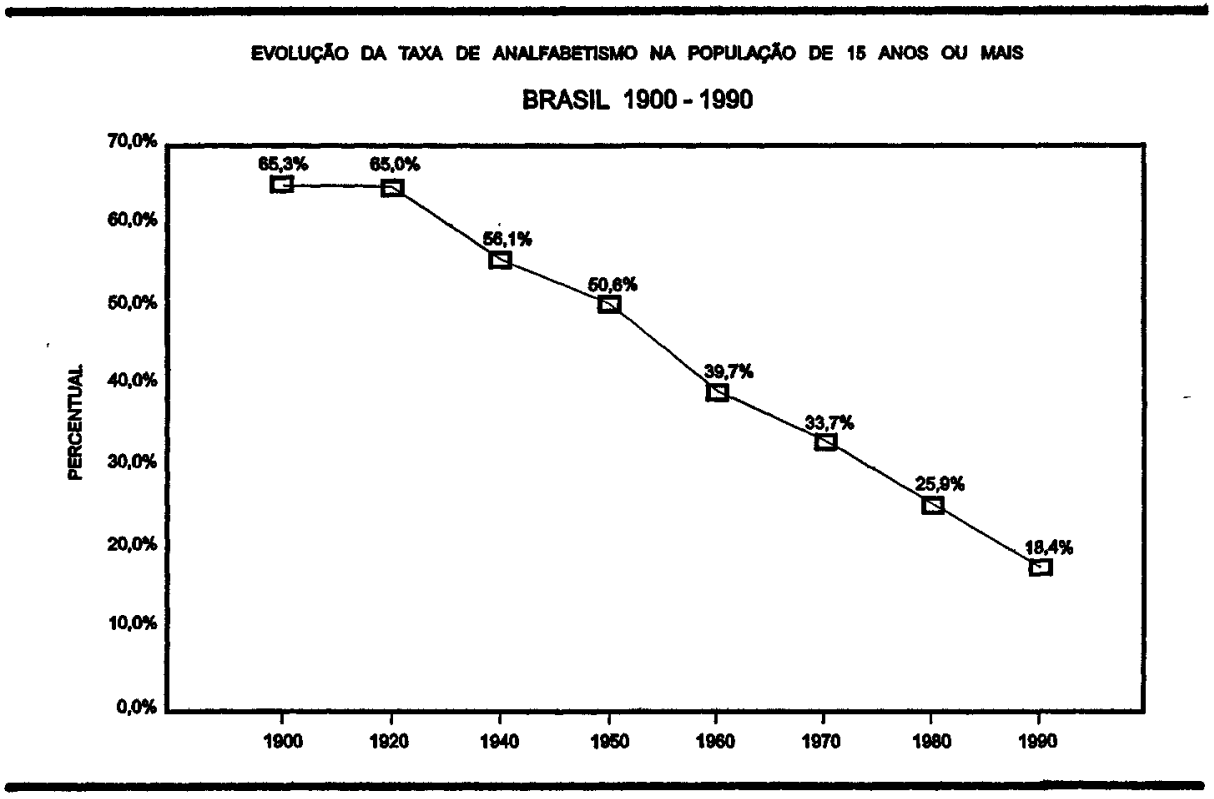

FONTE : IBGE

Esta foi exatamente a ćpoca considerada como uma espécie de idade de ouro da escola pública brasileira. Realmente, muitas daquelas 3,8 milhóes de crianças tiveram a oportunidade de estudar em excelentes escolas estaduais ou mesmo federais, como o Colégio Pedro II, no Rio. Eram, na sua grande maioria, provenientes de famílias de classe média. Os filhos das famílias mais pobres simplesmente não iam à escola e não tinham escolas para onde ir. A qualidade foi assim conseguida e mantida graças à brutal exclusão da populaçáo pobre. 
A universalização do acesso começou nesse período: em 1960, $45 \%$ das crianças iam à escola; em 1970,67\%; em 1980, 80\% e em $1990,88 \%$.

A figura 7 mostra a associação entre o declínio do analfabetismo e a progressão da universalização do ensino fundamental.

\section{FIGURA 7}

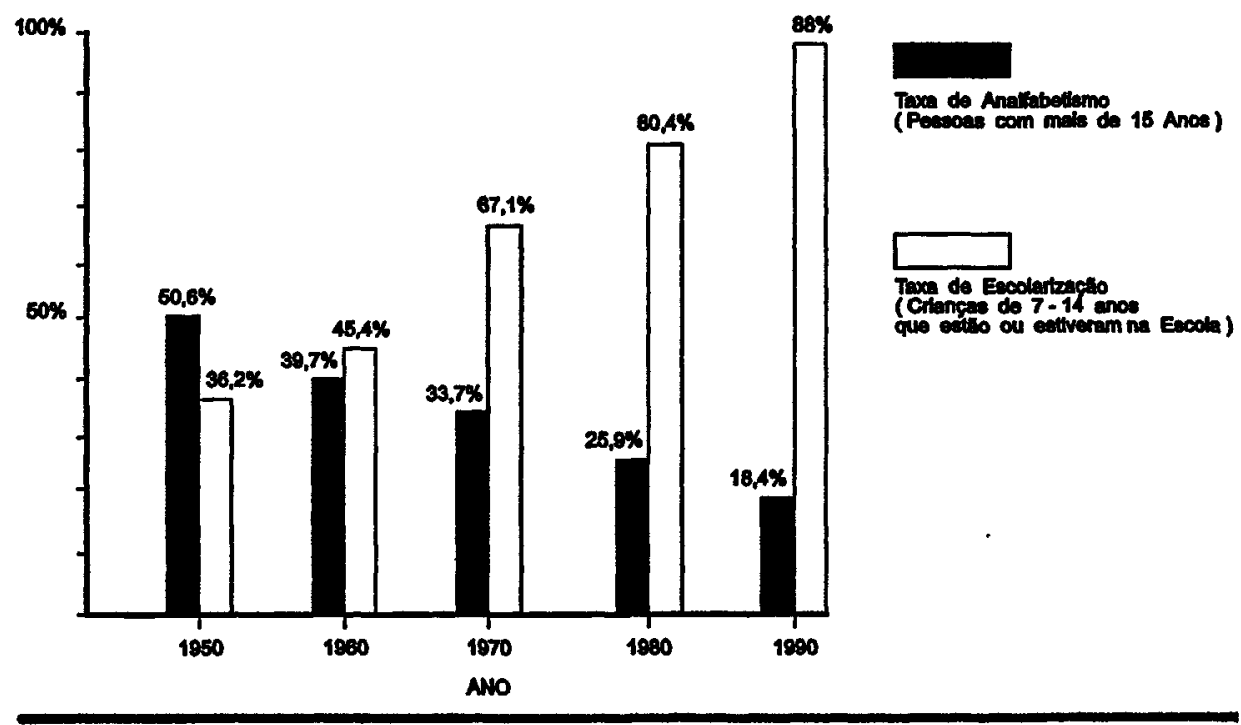

FONTE :-MEC - SAG

Precisamos reconhecer que a existência de $12 \%$ de crianças entre 7 e 14 anos fora da escola é dado preocupante, como preocupante também é a taxa de $18,4 \%$ de jovens e adultos analfabetos. Mas, para resolver tal problema, precisamos saber quem são essas crianças e esses adultos.

A figura 8 nos dá a idéia dessa distribuiçáo, assim como da elevada associaçáo entre analfabetismo e pobreza. Como se vê, o analfabetismo entre a população de 10 a 14 anos é residual nas famílias cuja renda familiar per capita é superior a dois salários mínimos, quaisquer que sejam as regiōes onde vivam - mesmo no Nordeste não atingem $3 \%$.

As taxas mais elevadas aparecem na populaçáo mais pobre, na qual a renda per capita é inferior a meio salário mínimo. Nessa faixa de renda, para o Brasil em geral, o percentual de analfabetos cresce para $30 \%$. Mas 


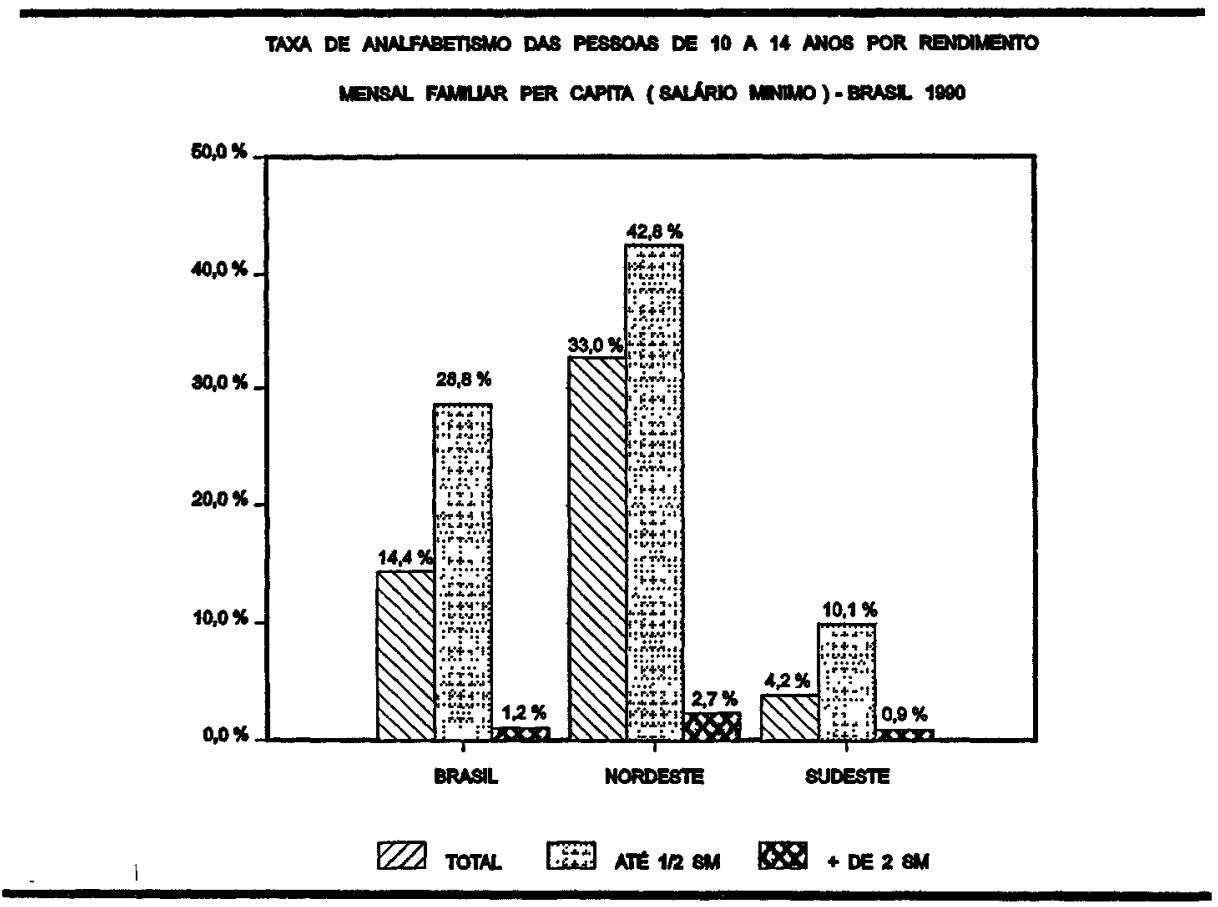

FONTE : IBGE - PNAD

não se trata de distribuição uniforme em todo o país - ao contrário, há uma forte concentraçáo no Nordeste, onde $43 \%$ das crianças das famílias mais pobres são analfabetas, o que é um dado alarmante. No Sudestc, por outro lado, considerando a mesma faixa de renda, o analfabetismo infantil e juvenil cai para $10 \%$.

Se considerarmos agora as crianças fora da escola, confirmamos os mesmos resultados. Dados anteriores da Pesquisa Nacional por Amostra de Domicílios (PNAD), de 1988 (8), indicavam que, das crianças entre 7 e 14 anos, $81,2 \%$ estavam freqüentando o $1^{\circ}$ grau e $2,4 \%$ a pré-escola (figura 9), ou seja, $83,6 \%$ estavam na escola.

Daquelas fora da escola, 3,6\% estavam aguardando ingresso e provavelmente acabariam por matricular-se no $1^{\frac{9}{0}}$ grau, embora com algum atraso; $7,5 \%$ já tinham freqüentado a escola, mas haviam-na abandonado sem concluir a escolarização básica obrigatória; apenas os $\mathbf{5 , 3 \%}$ restantes efetivamente estavam e provavelmente permaneceriam fora da escola $-70 \%$ dessas crianças estavam localizadas no Nordeste rural.

Analfabetos adultos e crianças sem escola localizam-se na mesma 


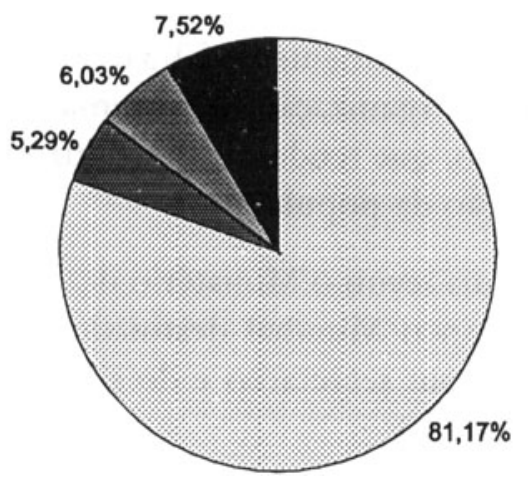

FONTE : PNAD - 88

Ribelro Sérgio Costa. "A pedagogia da repetencia ".

Estudos Avangados 12 (5), 1991

regiáo, onde a cxtrema pobreza constitui certamentc um problema mais sério e mais grave do que o analfabetismo, o qual é conseqüência dessa situaçáo de miséria.

Dessa maneira, pode-se concluir que a erradicaçáo do analfabetismo e a universalização do acesso à escola náo constituem objetivos a serem perseguidos uniformemente em todo o território nacional. No Sudeste, por exemplo, com um mínimo de incentivos, o problema será resolvido, pois já está equacionado. A União, no seu papel supletivo e redistributivo, deve concentrar seus esforços no Nordeste rural pobre, onde não basta simplesmente construir escolas, mas também é preciso combater a pobreza e minorar os seus efeitos através de auxílios como merenda escolar, da qual trataremos mais tarde. O papel da União nesses municípios é fundamental, embora difícil, pois a pobreza da população está freqüentemente associada à pequena participação política, à incapacidade de controlar os orçamentos municipais, à ausência de recursos das prefeituras $e$, inclusive, às vezes, ao desinteresse de prefeitos e vereadores.

Como os problemas de acesso à escola são localizados e específicos, a política do Ministério da Educação, que é de caráter supletivo e 
redistributivo, deve, portanto, ser dirigida de forma a atacar as questóes mais graves.

A primeira delas diz respeito aos bolsóes de pobreza, especialmente os da zona rural, os quais se concentram, em grande parte, no Nordeste. Năo se trata, neste caso, simplesmente de falta de escolas mas, inclusive, de deficiências na própria organizaçáo do sistema de ensino por parte das secretarias de Educação, que tendem a reproduzir e a perpetuar os problemas de escolarização da população.

O reconhecimento do problema levou o Ministério da Educação a negociar um empréstimo com o Banco Mundial destinado especificamente a melhorar o desempenho dessas secretarias e do sistema educacional como um todo.

O empréstimo tem componentes importantes de treinamento e retreinamento de professores, de melhoria das condiçóes físicas de ensino e do material educacional, mas a sua finalidade principal é estimular os estados a melhorarem o gerenciamento do sistema.

É notório que, em alguns estados do Nordeste, fração apreciável dos recursos destinados à educação (quer de origem estadual ou federal) náo chega às escolas por uma variedade de razóes:

- excesso de funcionários administrativos;

- número elevado de professores fora da sala de aula lotados em outras áreas do Governo;

- extrema ineficácia dos procedimentos burocráticos.

A figura 10 ilustra esse problema, indicando os gastos relativos com a administração e com o funcionamento das escolas em dois estados: São Paulo e Piauí.

Combinando tais problemas com a conseqüente contrataçáo indiscriminada de leigos, não é de surpreender a ineficiência do sistema. Ocorrem situaçốes absurdas, como o excesso de funcionáriós no sistema e falta de professores nas salas de aula. Por outro lado, o excesso de pessoal faz com que os salários sejam baixos, impedindo a melhoria do nível do corpo docente.

A concessão do empréstimo do Banco Mundial está condicionada a esforços planejados pelos governos estaduais para a correçáo da situaçăo, melhorando a eficiência do sistema. Dessa forma, o Ministério da Educaçáo adquire um instrumento de pressão que não tem no presente, o qual lhe permitirá atacar as causas do problema, em lugar de, simplesmente, procurar corrigir os sintomas. 


\section{FIGURA 10}

\section{CUSTO ALNO/ANO ESTADUAL EM BAO PALLO}

Custo Direto - Custo Indineto

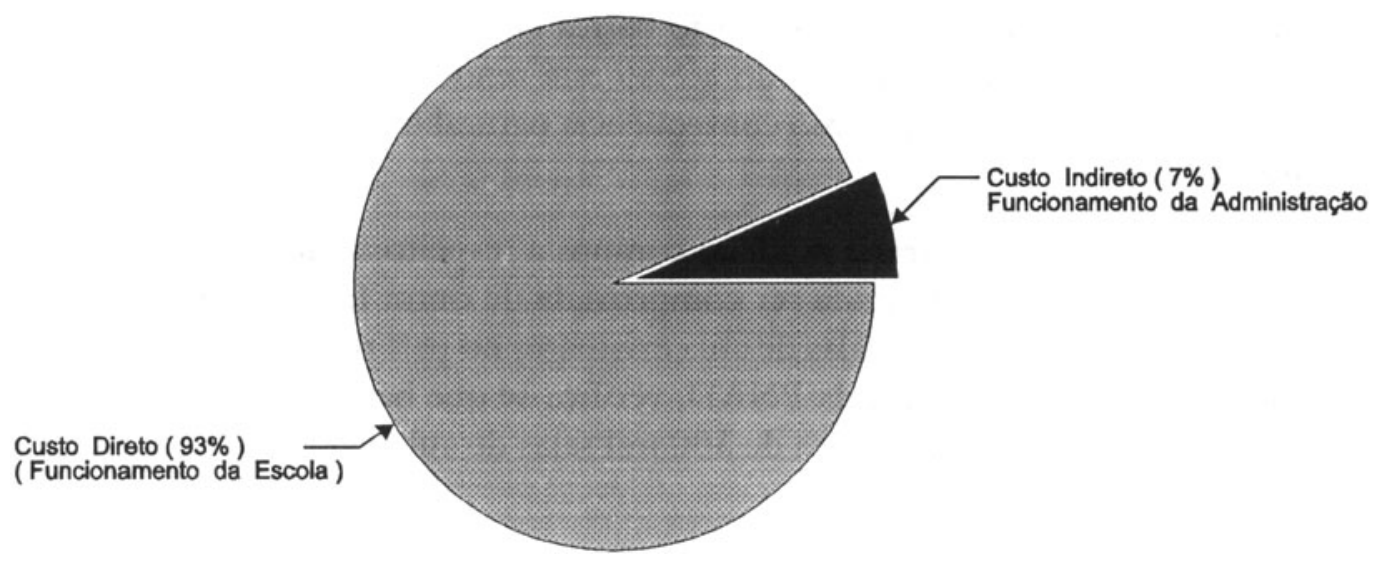

FONTE : Xavier e Marques

CUSTO ALUNO/ANO ESTADUAL NO PLAUI Custo Direto - Custo Indineto

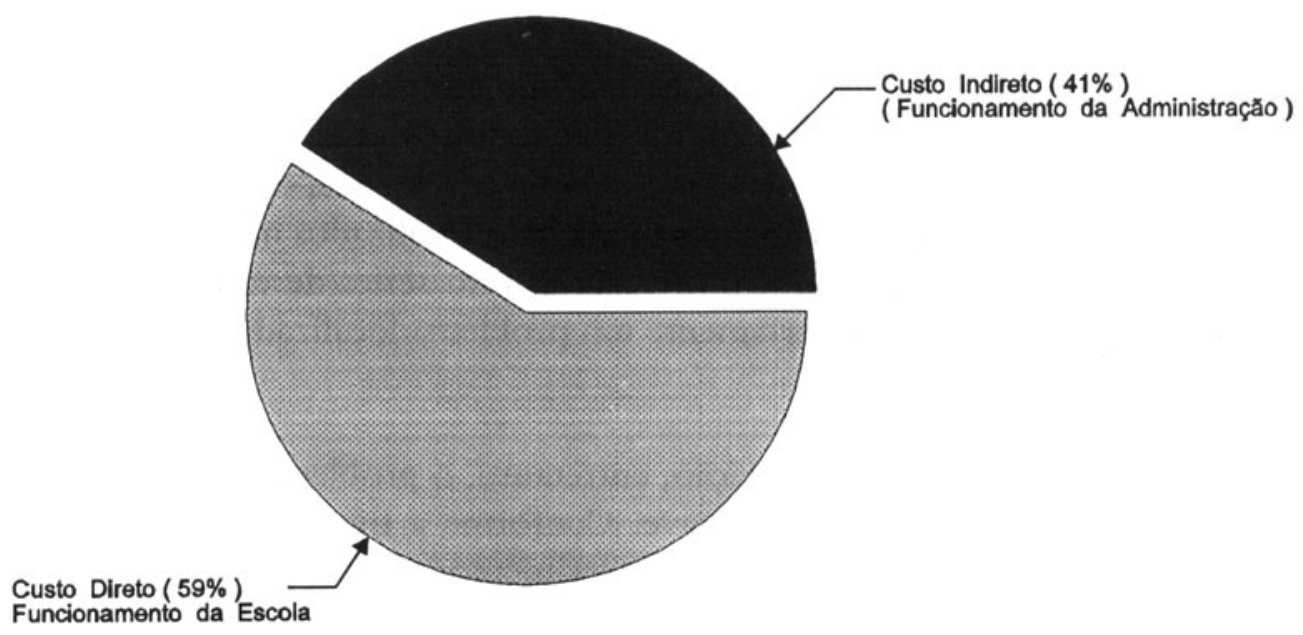




\section{A rede fisica das escolas puiblicas}

A conclusão da análise que fizemos é que, com exceção dos bolsóes de pobreza localizados no Nordeste rural e em algumas periferias urbanas, o problema central da educação básica no Brasil não reside na falta de escolas. A universalização do acesso está sendo feita e o analfabetismo está desaparecendo como conseqüência natural da escolarização universal.

Essa afirmação contraria as idéias comuns a respeito do nosso sistema de ensino, mas pode ainda ser comprovada de outra forma: pelos dados referentes às escolas e salas de aula existentes no país para o ensino público. Utilizando os dados da PNAD, verifica-se que havia no Brasil, em 1988, 227.192 escolas e cerca de 500 mil salas de aula para o ensino de $1^{\circ}$ grau.

Tomando-se o número de matrículas no $1^{\circ}$ grau daquele ano, que era de cerca de 27 milhóes de crianças, e dividindo-se o total pelas salas de aula existentes, obtém-se uma média (grosseira, é verdade, mas significativa) de 54 alunos por sala. Considerando-se um míniıno de dois turnos nas escolas, como é a tradiçăo brasileira, e as crianças distribuídas uniformemente, haveria 27 alunos por sala em cada período. Os problemas não se localizam, portanto, na falta generalizada de escolas, mas na sua distribuição.

A tabela 15 indica a distribuição das escolas em função do número de salas de aula que possuem e a tabela 16 nos dá o número de matrículas de $1^{\circ}$ grau nesses diferentes tipos de estabclecimento escolar.

Como pode ser verificado, há um número demasiado grande de escolas de sala única, que somam $60 \%$ de todos os estabelecimentos de ensino e abrigam $11 \%$ dos estudantes. Como era de se esperar, a maioria dessas escolas são estabelecimentos municipais localizados na zona rural. Escolas como estas não podem oferecer as oito séries de escolarização obrigatória e constituem certamente um problema localizado que precisa ser enfrentado.

Para a maioria da populaçáo, entretanto, o problema do acesso a escolas mais completas não é grave. Conforme a figura $10,79 \%$ das crianças brasileiras estudam em estabelecimentos com mais de 150 alunos e outros $10 \%$ estáo em escolas que possuem entre 51 e 150 estudantes; 12 milhóes estão em escolas com mais de 10 salas de aula e outros sete em estabelecimentos que possuem entre seis e 10 salas (figura 11 ). 
Ensino Regular de 10 Grau - 1988

Número de Estabelecimentos por Número de Salas de Aula por Localização

\begin{tabular}{lrrrrrr}
\hline & \multicolumn{5}{c}{ Número de salas de aula } \\
Regiáo & 1 & $2-5$ & $6-10$ & $\begin{array}{r}\text { mais } \\
\text { de } 10\end{array}$ & $\begin{array}{l}\text { total de } \\
\text { escolas }\end{array}$ \\
\hline & & & & & \\
Brasil (total) & 136.795 & 53.950 & 20.641 & 15.806 & 227.192 \\
Zona rural & 129.433 & 33.143 & 1.702 & 534 & 164.812 \\
\hline
\end{tabular}

Fonte: MEC-SAG-CPS-CIP.

Tabela 16

Ensino Regular de 1\% Grau - 1988

Número de Matrículas por Tipo de Estabelecimento

(Número de Salas de Aula) por Localizaçáo

\begin{tabular}{lcccccc}
\hline & \multicolumn{5}{c}{ Número de matrículas } \\
Regiấo & 1 & $2-5$ & $6-10$ & \multicolumn{1}{c}{ mais } & \multicolumn{1}{c}{ total de } \\
matrículas
\end{tabular}

Fonte: IBGE-PNAD.

A situaçáo desigual das escolas pode ser aferida a partir do número de turnos que elas possuem. Escolas que funcionam em apenas um turno (em geral, as de classe única e com um só professor) representam $58 \%$ do total. Escolas desse tipo, portanto, náo só oferecem uma escolarização parcial, mas representam um subaproveitamento da capacidade física instalada.

Por outro lado, $4,8 \%$ das escolas, geralmente as maiores, funcionam em três ou quatro turnos. Estas escolas săo freqüientadas por 11 milhóes de estudantes, isto é, cerca de $\mathbf{4 0 \%}$ do total de alunos.

Estabelecimentos de ensino de três turnos, em zonas urbanas, não configuram necessariamente uma situaçáo de superlotação das escolas. 


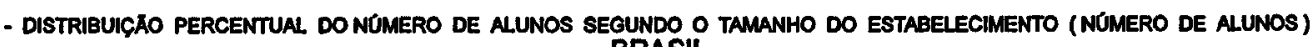
BRASIL

1987

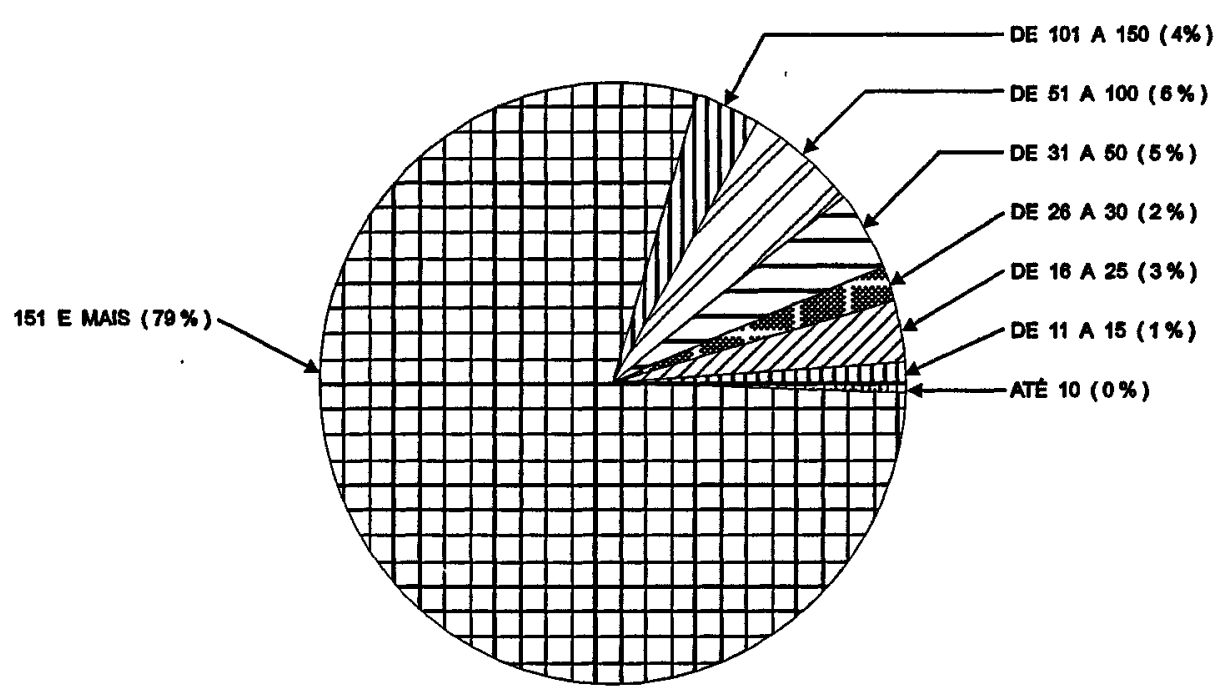

Quando o $3^{\circ}$ período é noturno, é possível, no mesmo prédio, oferecer de quatro a cinco horas de aulas diariamente a cada criança, o que, nas condiçóes brasileiras, poderia constituir situação aceitável. $O$ problema se coloca quando há três períodos diurnos, com ou sem noturno adicional. Nesses casos, o número de horas de aula fica seriamente prejudicado; é nesses estabelecimentos que ocorre efetiva superpopulação.

A superlotaçáo de escolas tende a ocorrer nas periferias das grandes cidades e decorre dos movimentos de migraçäo interna. $\mathrm{O}$ crescimento às vezes explosivo de bairros periféricos, à revelia de qualquer planejamento urbano, é o responsável pelo fato de haver, eventualmente, na mesma cidade, escolas com capacidade ociosa nas regióes mais antigas e outras funcionando com quatro turnos nas regiōes mais novas. $\mathrm{Na}$ maioria dos municípios o problema acaba sendo resolvido com a construção de novos prédios escolares, o que não pode ser feito instantâneamente $\mathrm{e}$, quando a populaçáo cresce muito aceleradamente, mesmo com um bom plancjamento, é impossível evitar deficiências temporárias no atendimento.

Para que problemas temporários não se transformem em permanentes é preciso a manutençáo de um fluxo regular de investimentos nos 
prédios escolares. A União atua decisivamente na manutenção desse fluxo através dos recursos do FNDE; responsável pela construçáo de cerca de 15 mil salas de aula por ano, o que representa $3 \%$ das salas existentes atualmente e corresponde ao crescimento populacional.

Se há, de maneira geral, escolas suficientes e se a construçáo de novos prédios - que vem ocorrendo - tende a resolver o problema de necessidades localizadas e a acompanhar o crescimento da população, há que se avaliar se os prédios são satisfatórios.

Em meados da década dos 80, o MEC fez um levantamento do estado físico da rede escolar com resultados desencorajadores: em $27 \%$ delas não havia água corrente, em $50 \%$ faltava luz elétrica, giz e material didático, e, em significativo número das escolas, até cadeiras e mesas.

A fim de esclarecer a questão, o MEC realizou nova pesquisa, em 1992, distinguindo as escolas urbanas das rurais. Essa distinçáo é essencial, porque não se pode esperar que as escolas rurais tenham condiçóes muito superiores às do ambiente no qual foram implantadas (como esgoto, por exemplo). Já nas zonas urbanas, onde está concentrada a maioria dos alunos, a expectativa é de que as escolas sejam melhores.

Com efeito, o que a pesquisa mostrou é encorajador, como verifica-se nas tabelas 17 e 18 . Globalmente, $44 \%$ dos prédios escolares foram considerados ótimos e bons, e apenas $17 \%$ ruins ou péssimos; os demais (39\%), considerados regulares. Em São Paulo, Rio Grande do Sul, Ceará e Goiás cerca de $60 \%$ foram classificados como ótimos ou bons.

Mais ainda, nas áreas urbanas de Sáo Paulo, Rio Grande do Sul, Minas Gcrais, Ceará e Bahia, mais de $99 \%$ das escolas têm luz elétrica e abastecimento de água, bem como esgotos. Instalaçóes sanitárias foram consideradas bons ou regulares em mais de $\mathbf{8 0} \%$ dos casos, exceto nas zonas rurais da Bahia, Ceará e Minas Gerais.

O quadro negro (e giz) existe em mais de $90 \%$ de todos os estados, mas faltam cadeiras e mesas em 10 a $25 \%$ dos casos, sobretudo nas áreas rurais. Mais de $\mathbf{8 0 \%}$ das escolas dispóem de cozinha para preparo de merenda escolar.

Em alguns poucos estados a situaçáo é pior, acompanhando a situação geral da população. Generalizar o pior para todo o Brasil é, contudo, incorreto.

Em termos de quantidade e qualidade de prédios escolares, verifi- 


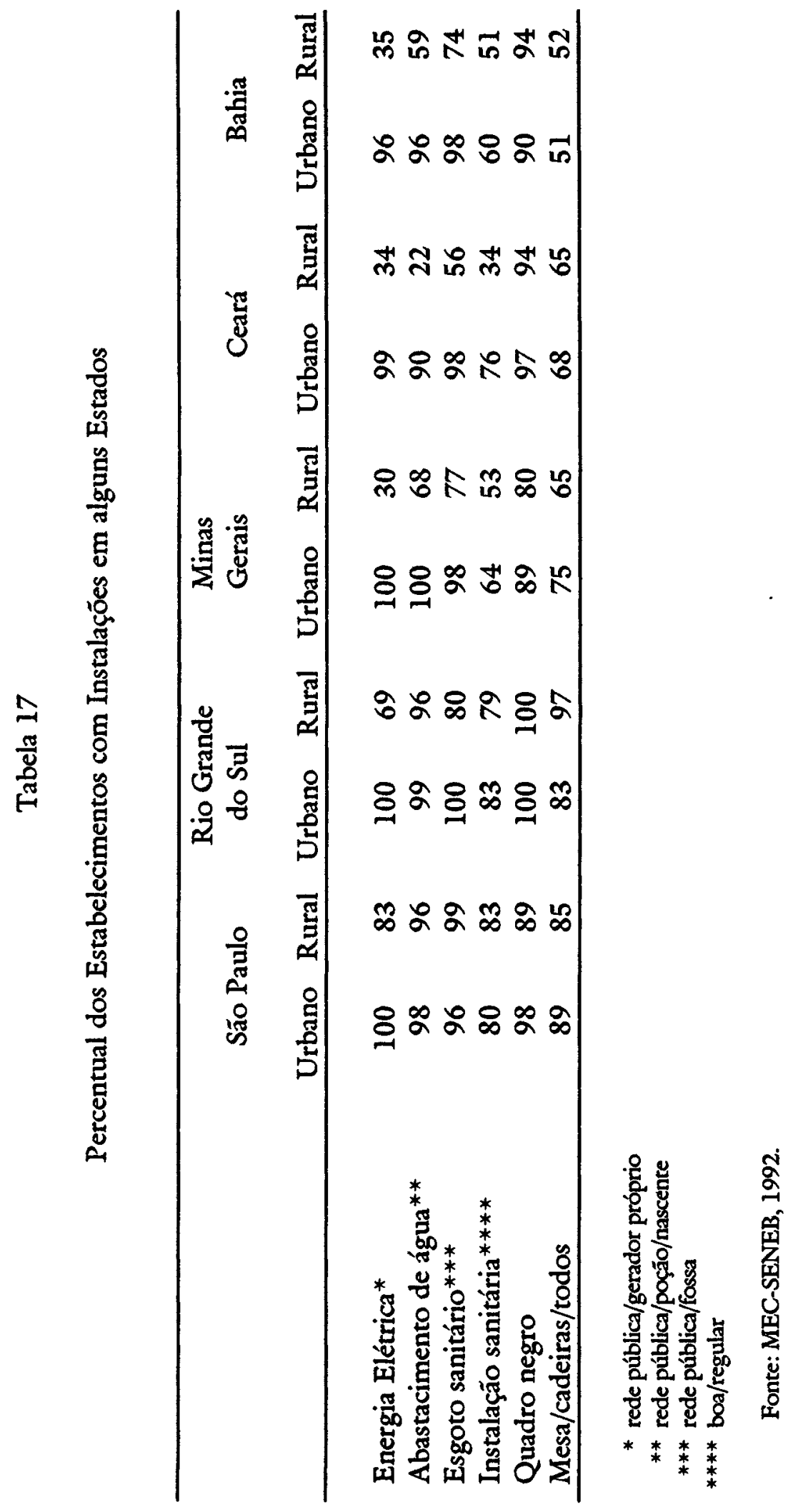


Tabela 18

Situação Geral do Prédio (\%)

\begin{tabular}{lccc}
\hline Estados & Ótimo/Bom & Regular & Ruim/Péssimo \\
\hline & & & \\
São Paulo & 55 & 34 & 11 \\
Minas Gerais & 47 & 38 & 14 \\
Bahia & 34 & 47 & 19 \\
Piauí & 28 & 55 & 17 \\
Ceará & 66 & 27 & 6 \\
Rio Grande do Norte & 26 & 47 & 27 \\
Amazonas & 20 & 48 & 31 \\
Rio de Janeiro & 45 & 37 & 19 \\
Pernambuco & 43 & 44 & 14 \\
Rondônia & 37 & 39 & 25 \\
Pará & 29 & 52 & 19 \\
Mato Grosso do Sul & 59 & 31 & 9 \\
Roraima & 44 & 34 & 20 \\
Acre & 30 & 46 & 24 \\
Sergipe & 45 & 41 & 14 \\
Alagoas & 34 & 43 & 23 \\
Espírito Santo & 32 & 46 & 23 \\
Distrito Federal & 40 & 41 & 20 \\
Paraná & 58 & 29 & 12 \\
Rio Grande do Sul & 74 & 23 & 3 \\
Santa Catarina & 64 & 25 & 10 \\
Mato Grosso & 42 & 39 & 19 \\
Maranháo & 57 & 30 & 13 \\
Amapá & 71 & 29 & 0 \\
Paraíba & 36 & 47 & 17 \\
Goiás & 59 & 31 & 11 \\
Tocantins & 19 & 40 & 41 \\
Média & 44 & 39 & 17 \\
\hline
\end{tabular}

Fonte: MEC-SENEB, 1992.

ca-se que os problemas se concentram nas escolas de sala única da zona rural e nas periferias das grandes cidades.

Com relação à primeira questão, o problema é grave, porque, como vimos, pequenas escolas rurais, de uma ou duas salas; são incapa- 
zes de oferecer a escolarização completa de oito séries. Neste caso, dada a rarefação da população, a soluçáa não se encontra em ampliar estas escolas, mas em oferecer condiçôes para que crianças de uma área mais extensa se concentrem em escolas maiores e mais completas.

No início de 1992, o MEC tentou, através de projeto de lei enviado ao Congresso, criar um programa de doação de ônibus escolares para os municípios onde o problema se manifestasse com maior intensidade, permitindo que as crianças freqüentassem escolas de oito séries situadas à maior distância. Infelizmente, a incompreensão dos deputados, que se recusaram a aceitar critérios objetivos para distribuição dos veículos, tornou o programa inviável, levando ao seu cancelamento. Mas, certamente, há necessidade de se voltar a propor solução desse tipo para resolver os problemas da população rural, que hoje concentra as taxas mais elevadas de analfabetismo e de falta de acesso à escola.

Outro problema que se apresenta é o referente às periferias urbanas, onde as deficiências decorrem do intenso crescimento da populaçáo causado pelas migraçóes internas, cuja tendência, como vimos, é serem resolvidos pelo ritmo normal das construçóes escolares.

\section{Evasão e repetência}

Se os indicadores relativos à universalização do acesso à escola e à diminuição do analfabetismo sáo animadores, os dados relativos ao percentual de crianças que completam as oito séries do ensino fundamental obrigatório são ainda muito preocupantes.

Houve, é certo, algum progresso. Em 1981, apenas 16\% dos alunos que haviam ingressado oito anos antes lograram completar o $1^{\circ}$ grau. Já em 1988, o percentual de concluintes elevara-se a $27 \%$ (figura 12).

Até recentemente, a baixa taxa de sucesso era atribuída, basicamente, ao problema da evasão escolar. Os trabalhos mais recentes colocam, na raiz do problema, o fenômeno da repetência. Se se considerar como evasão o abandono precoce da escola após um ou dois anos de frequiência, como se supunha antigamente, pode-se dizer que a taxa de evasão é mínima. Os primeiros estudos realizados a partir da PNAD de 1982 indicavam que a evasão não ultrapassava $2,3 \%$ entre a $1^{\text {a }}$ e a $2^{\text {a }}$ séries. A repetência, em compensação, era altíssima, atingindo $52,4 \%$ (tabela 19). 


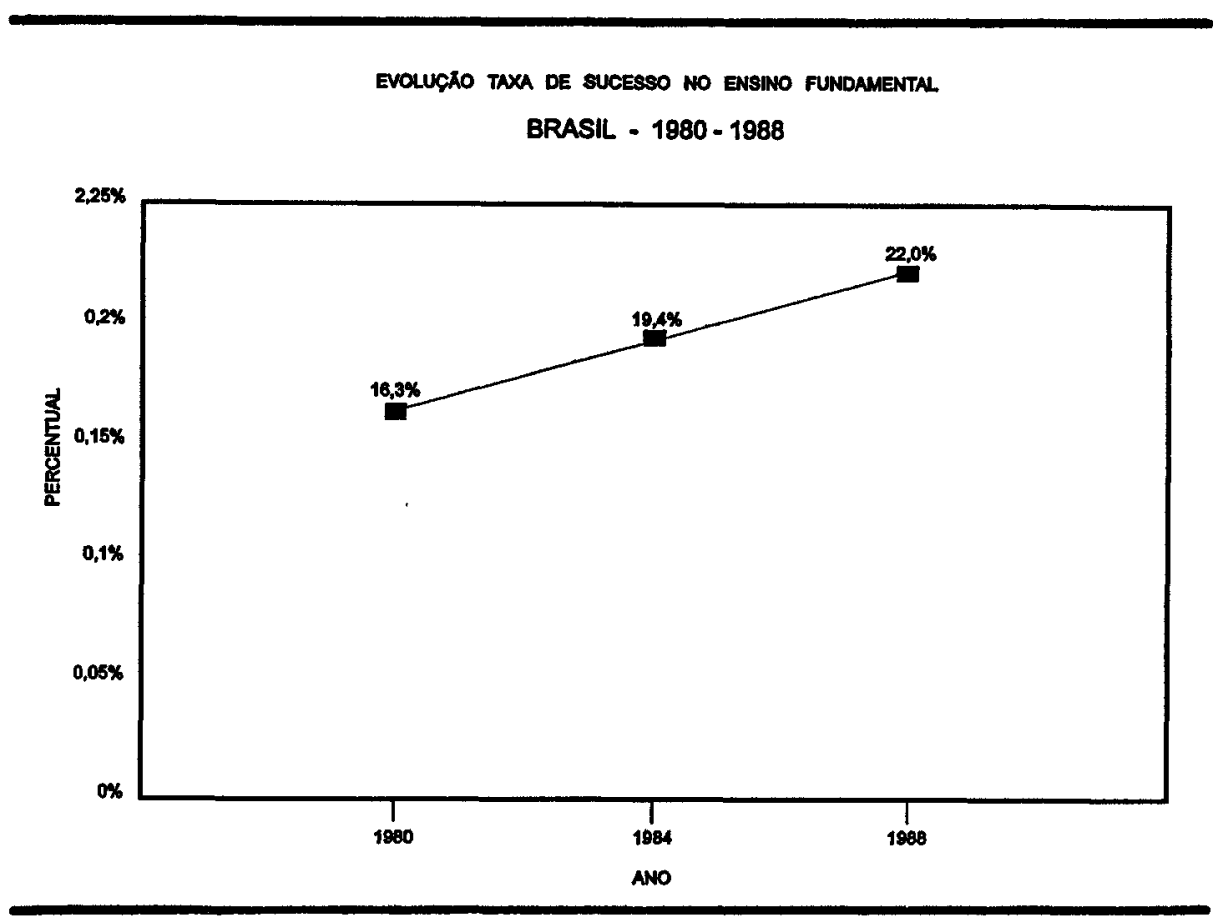

FONTE : MEC

Tabela 19

Repetência, Promoção e Evasáo em 1982 Modelo PROFLUXO

\begin{tabular}{lccc}
\hline Série & Repetência & Promoção & Evasáo \\
\hline $1^{\mathbf{a}}$ & 0,524 & 0,453 & 0,023 \\
$2^{\mathbf{a}}$ & 0,342 & 0,616 & 0,042 \\
$3^{\text {a }}$ & 0,265 & 0,665 & 0,070 \\
$4^{\text {a }}$ & 0,215 & 0,601 & 0,184 \\
$5^{\mathbf{a}}$ & 0,328 & 0,597 & 0,085 \\
$6^{\mathbf{a}}$ & 0,192 & 0,720 & 0,088 \\
$7^{\mathbf{a}}$ & 0,165 & 0,729 & 0,107 \\
$8^{\mathbf{a}}$ & 0,195 & 0,603 & 0,202 \\
\hline
\end{tabular}

Fonte: Modelo PROFLUXO, aplicado aos dados da PNAD (Ribeiro, 1991).

Tais dados confirmam ser incorreta a idéia muito generalizada de que há enorme número de crianças fora da escola de $1^{\circ}$ grau em virtude 
de evasão. Na realidade, a grande maioria das crianças ingressa na escola na idade correta e permanece nela, mas simplesmente não progride, ficando prisioneira da repetência e inflacionando o número de matrículas na primeira série. $O$ abandono da escola se dá, geralmente, após a $4^{\mathrm{a}}$ série, ou seja, depois de terminado o equivalente à antiga escola primária; e somente ocorre depois de as crianças já terem permanecido aproximadamente oito anos no sistema.

$\Lambda$ tabela 20 indica of fluxo escolar, isto é, acompanha as matrículas, série por série, em anos sucessivos. $\mathrm{O}$ mesmo faz a figura 13 . Assim, havia seis milhóes e meio de crianças matriculadas na $1^{\text {a }}$ série em 1978 (incluindo os repetentes). No ano seguinte, estavam na $2^{\mathrm{a}}$ série pouco mais da metade, ou seja, três milhóes e seiscentos mil. Quatro anos depois, matricularam-se na $4^{\mathrm{a}}$ série apenas dois milhões e quatrocentos mil, ou, $37,2 \%$ do contingente inicial.

\section{FIGURA 13}

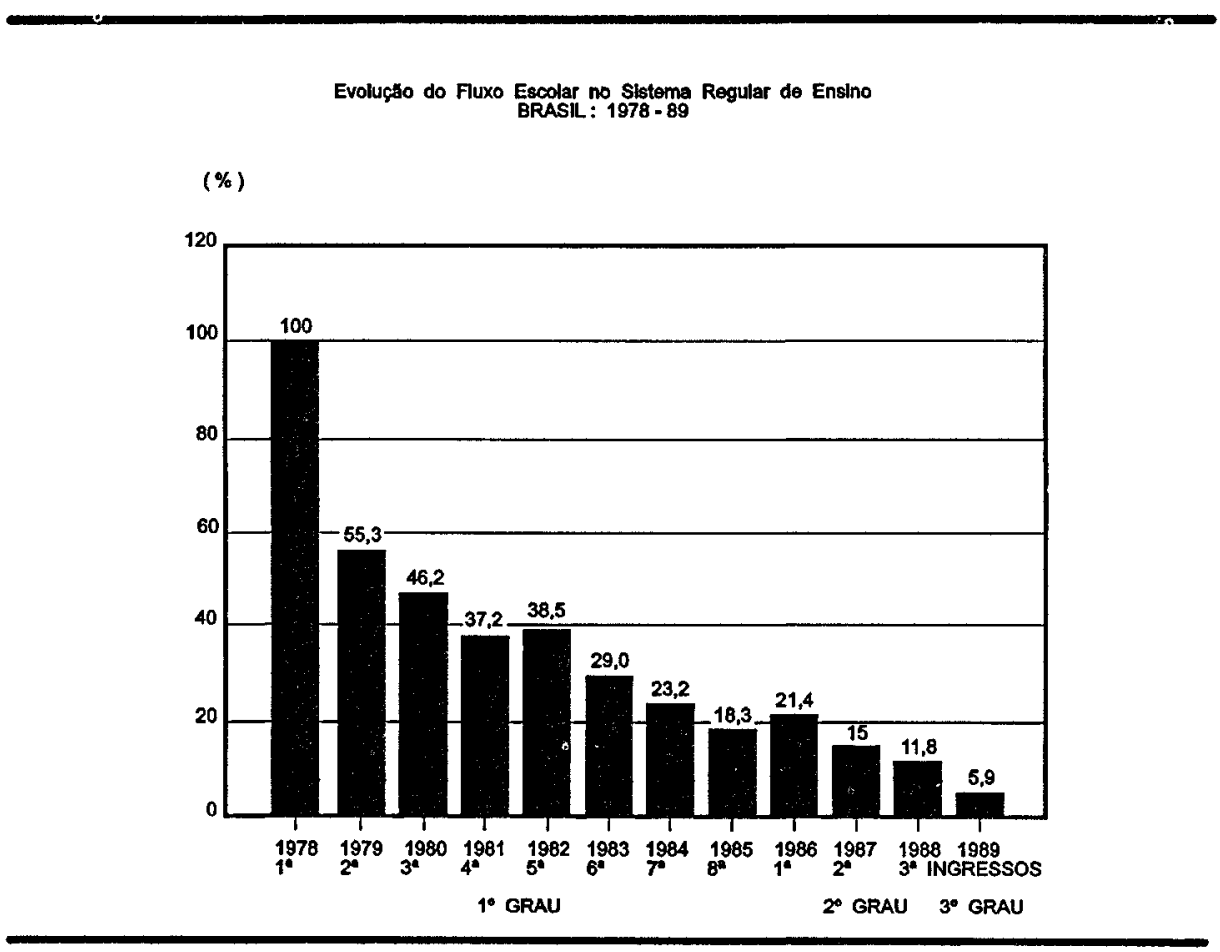

FONTE : MEC - SAG - CPS - CIP

O interessante ocorre no ano seguinte: as matrículas na $5^{\mathbf{a}}$ série ultrapassam dois milhóes e meio, isto é, são maiores do que na $4^{\text {a }}$, 
indicando claramente haver represamento na $5^{\mathrm{a}}$ série por elevado número de repetentes, os quais aumentam desproporcionalmente o número de matrículas. Exatamente o mesmo fenômeno ocorre com a 1 a série do $2^{\circ}$ grau, na qual as matrículas também são superiores às da $8^{a}$ série do $1 \%$ grau no ano anterior.

Aceitando-se o fato incontestável de que as crianças estão na escola, a tabela 20 não pode mais ser interpretada como indicativa de alta evasão, mas de elevada repetência.

Por esses dados conclui-se que a população envia os filhos à escola e os mantém lá. A escola, portanto, é a responsável pela questão: recebendo as crianças, é incapaz de lhes transmitir o conhecimento e as habilidades necessárias para que consigam atingir a $8^{\mathrm{a}}$ série $\mathrm{em}$ oito anos ou pouco mais.

Tem-se tentado explicar tal fenômeno atribuindo a culpa do fracasso escolar às próprias crianças: carentes ou desnutridas seriam incapazes de aprender. Entretanto, essas mesmas crianças que fracassam na escola, aprendem fora dela a sobreviver em duríssimas condiçóes, inclusive provendo a própria subsistência e, às vezes, até a das famílias (mesmo que, em alguns casos, por meios ilegais ou francamente criminosos).

Há, na verdade, duas razóes para esse fracasso: a inadequação do currículo e a incompetência dos professores. Podemos admitir que crianças pobres, morando em favelas ou nas periferias urbanas, cujos pais não são escolarizados, em cujas casas não há material de leitura $\mathrm{e}$ muito menos lugar para estudar, tenham dificuldades em se adaptar a uma escola, um currículo e uma metodologia de ensino que pressupóem todas essas condiçōes, inclusive, informaçōes que as crianças pobres não possuem.

Mas as centenas de experiências pedagógicas feitas pelos mais diferentes grupos (e com as mais diferentes metodologias) sempre conseguem melhorar substancialmente o rendimento escolar das crianças de baixa renda. $O$ que caracteriza essas experiências é serem feitas por professores motivados, aptos e orientados. Professores preparados e interessados podem adaptar currículos a situações adversas. Náo se tem conseguido, porém, melhorar o rendimento para o conjunto do sistema (qualquer que seja a metodologia preconizada), uma vez que os professores são desinteressados, despreparados e mal pagos.

O cerne da atual política educacional, portanto, reside em melhorar a qualidade do professor para melhorar a qualidade do ensino, dimi- 


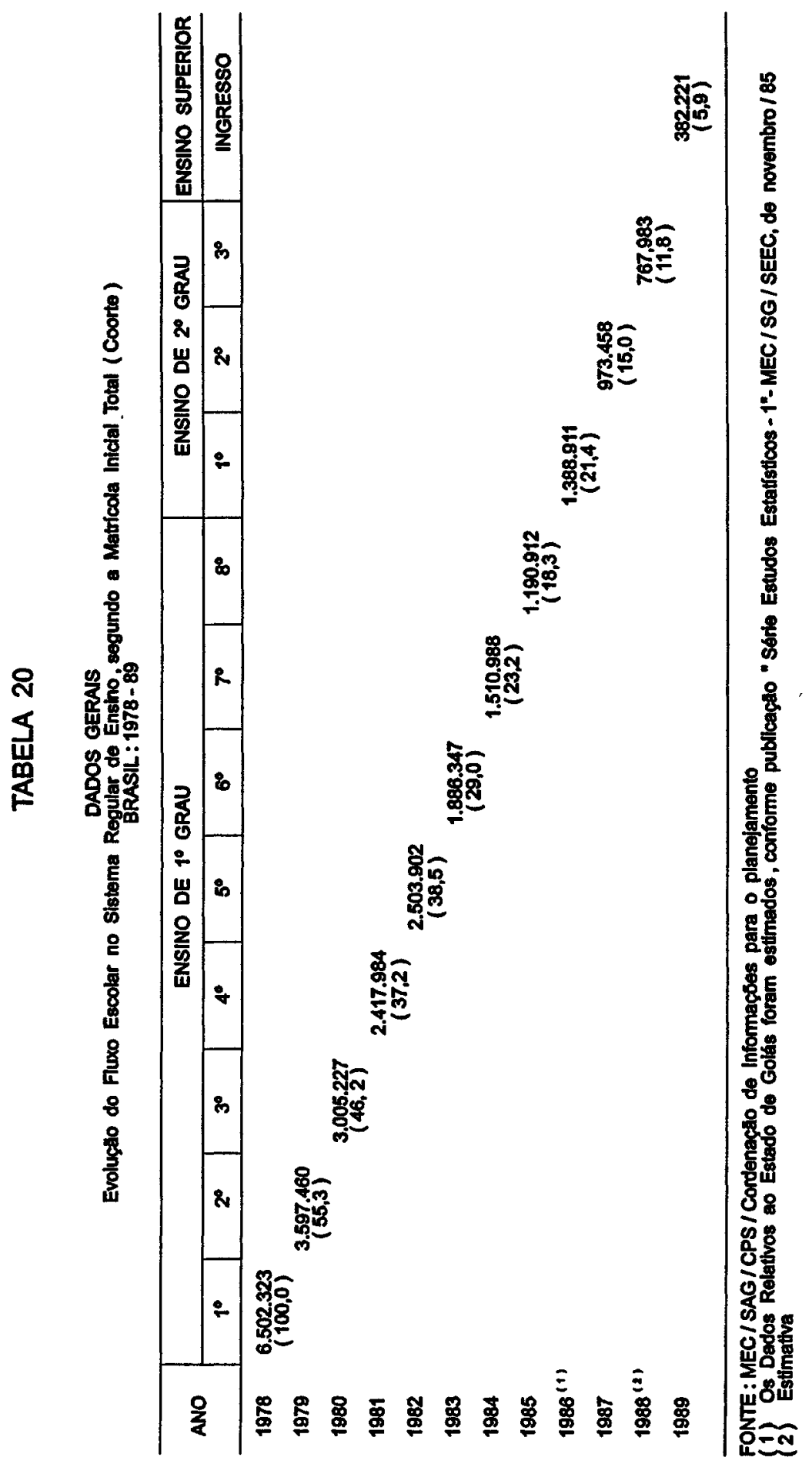


nuir a evasão e conseguir que a maioria das crianças brasileiras complete a $8^{\mathrm{a}}$ série.

Uma das iniciativas tomadas pelo Ministério para melhorar a qualidade dos professores foi o amplo programa de educação à distância conduzido pela TV Educativa, que passou a dedicar grande parte da sua programaçẫo a esta atividade.

A motivação e o preparo dos professores prendem-se a uma outra questão: a do contexto no qual trabalham. A ausência de autonomia das escolas e o peso dos controles puramente burocráticos dificultam enormemente a criação de um ambiente no qual professores e diretores sintam-se responsáveis pelo desempenho dos alunos. A melhoria do professor está associada à melhoria da escola como um todo.

\section{O Ministério da Educação e a melhoria da educação básica}

O Governo Federal tem poucos instrumentos eficazes para promover a melhoria da educação básica. Ele não é diretamente responsável pelo sistema público de $1^{\circ}$ grau - atribuição dos estados e municípios - e, como já referido, a maior parte dos recursos do Tesouro alocados ao Ministério da Educaçáo é destinada à educação superior. Se o Ministério dependesse apenas dessa fonte para influir na educação básica, ele seria praticamente impotente.

Não o é porque o Fundo Nacional de Desenvolvimento da Educação (FNDE) coloca à disposição do Ministério recursos vultosos e de aplicação flexível. Além disso, a Fundação de Amparo ao Estudante (FAE) opera basicamente com recursos do Finsocial. A política de utilização destes recursos constitui, portanto, o cerne da política federal para a educação fundamental.

Com os recursos do FNDE e da FAE, o Ministério conduz três programas de grande alcance:

- distribuição de recursos para os estados e municípios para a melhoria da sua atuação;

- programa da merenda escolar;

- programa do livro didático.

A tentativa mais ambiciosa do Governo Federal consistiu, entretanto, no projeto dos CIACs. O objetivo era duplo - atender à defi- 
ciência no número de escolas nas grandes periferias urbanas e promover $o$ atendimento mais completo, em tempo integral, que permitisse diminuir as taxas de evasão e repetência.

\section{O FNDE e o salário-educação}

O FNDE foi criado como fonte adicional ao financiamento do ensino: trata-se de uma contribuição patronal $(2,5 \%$ da folha de pagamento das empresas) destinada ao financiamento do ensino de $1^{\circ}$ grau, suplementando os recursos públicos destinados à manutenção e ao. desenvolvimento desse grau de ensino. Tal contribuição é chamada salário-educação e constitui um Fundo com recursos consideráveis: cerca de 1,5 bilhóes de dólares por ano. Somente são isentos de contribuir para ele os órgãos do próprio Poder Público e suas autarquias e instituições de ensino públicas e privadas.

O recolhimento dos recursos do salário-educaçáo pode ser feito de duas formas distintas, a critério das empresas contribuintes:

- ao FNDE, passando, neste caso, a integrar o SME - Sistema de Manutenção do Ensino de $1^{\circ}$ grau;

- ao INSS, juntamente com os recolhimentos usuais da Previdência Social;

Ao longo dos anos, a preferência por uma dessas formas tem variado; no presente, aproximadamente metade dos recursos ingressam em cada uma delas.

Os integrantes do SME podem deduzir aplicaçōes em escolas próprias. A dedução é calculada pelo custo de cada vaga (na realidade uma bolsa de estudos), cujo valor é fixado pelo Ministério da Educação. A empresa pode, também, adquirir vagas em escolas privadas de $1^{\circ}$ grau ou indenizar seus empregados ou dependentes por despesas feitas para estudar.

Um sério problema surgido com as deduçóes dos integrantes do SME refere-se à dificuldade de fiscalizá-las, sobretudo mais recentemente, devido ao aumento destas deduçóes, as quais têm desfalcado o Governo Federal de recursos que seriam utilizados para fins redistributivos. Esta é a principal razão pela qual o Ministério da Educação se opóe a tal sistemática, defendida por representantes do setor privado.

Do montante arrecadado em cada estado são creditados dois terços à respectiva Secretaria de Educação, Quota Estadual, que repre- 
senta cerca de um bilhão de dólares. $O$ terço restante - a Quota Federal (cerca de 500 milhóes de dólares) - é utilizado pelo Ministério da Educação, que pode repassá-lo a municípios, estados e até a entidades privadas devidamente credenciadas.

No passado, juros e correção monetária dos recursos do FNDE eram usados arbitrariamente pelo Ministério da Educação, para atividades culturais e até na área universitária, mas leis mais recentes corretamente eliminaram esta liberdade.

Com esses recursos, tanto da Quota Estadual quanto da Federal, constróem-se e reformam-se escolas, compram-se equipamentos escolares e treinam-se os professores. Só para dar uma idéia da importância do FNDE, basta dizer que com seus recursos são construídas, por ano, cerca de 10 mil salas de aula, as quais correspondem ao crescimento necessário para absorver o aumento anual da população escolar brasileira (cerca de $2 \%$ ao ano) e corrigir as distorçôes - na distribuiçáo das escolas e do número de salas de aula - decorrentes da movimentaçáo da população.

O Ministério não tem qualquer atuação na distribuição da Quota Estadual e os estados que mais contribuem sáo os que mais recebem, como é o caso de São Paulo. Já relativamente à Quota Federal, da qual o MEC pode dispor de acordo com seus próprios critérios, o bom senso indica que ela deveria ser distribuída para corrigir desequilíbrios regionais, concentrando recursos nos estados e municípios mais pobres. Tal procedimento seria um poderoso instrumento de política educacional. O problema fundamental referente à distribuiçáo dos recursos do FNDE é a demanda por recursos ser muito superior (cerca de duas a três vezes) à sua disponibilidade. Por outro lado, a própria flexibilidade na aplicaçáo dos recursos do Fundo, assim como o seu volume, tornam-no alvo de pressóes clientelistas, as mais diversas. Deputados e políticos em geral tentam direcionar a aplicaçáo dos recursos de acordo com os seus interesses, o que é feito de duas maneiras: ou obtendo do Ministro da Educação boa acolhida para suas propostas, ou incluindo no orçamento da Uniáo emendas específicas para beneficiar determinados municípios. A experiência demonstra que os recursos têm sido alocados com a utilização de critérios políticos, beneficiando municípios e estados de aliados do Governo, freqüentemente não aqueles que apresentam maiores carências de escolarização obrigatória.

A política que começou a ser implantada no Ministério da Educaçáo já no final de 1991, e começou a dar frutos em 1992, visava a alterar tal procedimento, estabelecendo critérios educacionais para a distri- 
buição dos recursos e dando transparência e objetividade a todo o processo.

A primeira prioridade consistiu em atender os municípios mais pobres. Para evitar a manipulação política na distribuiçáo, estabeleceram-se critérios objetivos para definir o grau de carência: número de crianças na faixa etária de sete a 14 anos e renda per capita. É por isso que estados como a Bahia receberam, no primeiro semestre de 1992, cerca de Cr\$ 80 bilhóes da Quota Federal do FNDE, enquanto São Paulo, apenas cerca de Cr\$ 20 bilhóes.

Foram criados comitês de educadores em todos os estados, os quais, conhecendo bem a situação local, podiam recomendar o atendimento e dar prioridade às necessidades mais prementes. De modo geral, mesmo com critérios que eliminam o supérfluo, as necessidades são maiores do que os recursos disponíveis. Assim, deu-se preferência à conclusão de obras já iniciadas, à recuperação dos prédios escolares e à aquisição de equipamentos e material escolar indispensáveis ao funcionamento das escolas. A construção de novas unidades e ampliação das existentes ficou condicionada à comprovação de necessidades no atendimento.

Esses procedimentos começaram a tornar impessoal a distribuição de recursos do salário-educação; a intermediação de verbas, ou por prestígio político ou por interesse econômico, começou a decrescer.

É importante não subestimar a oposição política que medidas desse tipo suscitaram e continuarão a suscitar. A prática política brasileira está demasiado impregnada pelo clientelismo e a obtenção de maioria no Congresso para medidas do interesse do Executivo tem sido tradicionalmente negociada através de concessão de cargos ou de distribuiçáo de recursos como os do FNDE. Mas tanto a moralidade da vida pública como a eficácia da política educacional passam necessariamente pela modificação das práticas viciadas do passads, e a implantação de critérios objetivos e impessoais na alocaçăo de re :ursos precisa ser efetivada.

Outra medida tomada com relação aos rccursos do FNDE encontrou menor resistência e pode revelar-se como extremamente eficaz na promoçáo da melhoria da qualidade do ensino. Consistiu no redirecionamento dos recursos, tradicionalmente usados quase que exclusivamente na construção e reforma de prédios escolares, para contemplar também o treinamento de professores, privilegiando açóes municipais ou intermunicipais de capacitação de recursos humanos, desde que articuladas com instituiçốes formadoras em níveis médio e superior. 
O Ministério procurou, ainda, contriburir para a melhoria salarial, que deve estar associada à elevação da qualificaçáo. Náo sendo (nem devendo ser) o pagamento dos professores de responsabilidade ou competência da União, a atuação neste nível deve ocorrer através de estímulos para que estados e municípios se empenhem nessa direção. Os recursos do FNDE passaram a desempenhar também esta função, pois sua liberaçáo envolveu uma negociação com governadores e prefeitos no sentido de associá-la ao estabelecimento de planos estaduais e municipais de carreira docente e melhoria salarial. Para auxiliar os projetos de aumento salarial, o MEC permitiu, inclusive, serem utilizados para tal fim os $30 \%$ da contraparte que municípios e estados deveriam oferecer para receber os recursos da União.

Com a correta utilização do FNDE, eliminadas as pressóes políticas sobre seu uso, há possibilidade de com ele serem feitos investimentos criativos, tanto na construçáo de escolas como na melhoria dos professores, os quais, na atual situação, estão se tornando o ponto de estrangulamento que impede a melhoria do ensino fundamental no país.

\section{A merenda escolar}

As deficiências do sistema escolar brasileiro e a pobreza da população são fenômenos intimamente associados, que precisam ser considerados conjuntamente. Para aquela parte da população brasileira realmente pobre, a educaçáo dos filhos não é a prioridade fundamental, mas o são a alimentaçáo, a moradia e a saúde. Para essas famílias, não basta o ensino ser gratuito - é preciso que a freqüência à escola não represente um ônus econômico adicional em termos de transporte e material didático. Além disso, se não houver provisão para a alimentação das crianças, muitas delas precisarão abandonar a escola para obter o seu próprio sustento.

Um dos problemas do $1^{\circ}$ grau, portanto, refere-se a que as escolas não podem ser apenas instituiçōes de ensino, mas, freqüentemente, precisam também ser restaurantes, ambulatórios e centros de assistência social.

O Art. 208, inciso VII, da Constituiçáo estabelece que "o dever do Estado com a educaçáo será efetivado mediante a garantia de atendimento ao educando, no ensino fundamental, através de programas suplementares de material didático escolar, alimentação e assistência à saúde". 
A União tem desempenhado um importante papel nesta área, no cumprimento de sua função supletiva. Merenda escolar, atendimento médico e livro didático são alguns dos serviços que o Ministério da Educaçăo presta na área social, através da Fundação de Amparo ao Estudante (FAE). Mas a Constituição estabelece, também, no seu Art. 212, parágrafo $4^{\circ}$, que "os programas suplementares de alimentaçáo e assistência à saúde serão financiados com recursos provenientes de contribuiçóes sociais e outros recursos orçamentários ". Isto significa que os $\mathbf{1 8 \%}$ da receita da União, resultantes de impostos (descontadas as transferências aos estados e municípios), não se destinam a cobrir tais atividades suplementares, sendo necessários outros recursos para viabilizá-las. Foi o que se tentou fazer quando a lei estabeleceu que o Finsocial deveria ser a principal fonte de recursos para os programas da área social.

Essa dependência dos programas com relaçáo ao Finsocial passou a constituir um problema extremamente sério no momento em que a constitucionalidade desse imposto começou a ser contestada e sua arrecadaçáo diminuiu drasticamente. Aliás, o mesmo ocorreu na área da saúde, cuja fonte de recursos é a mesma.

Existe correlaçáo pronunciada entre a merenda escolar e os índices de evasão e repetência. Essa correlação é mais forte nos estados e regióes mais pobres (inclusive nas periferias das cidades ricas), onde, náo raro, a criança vai à escola principalmente para se alimentar. O Programa da Merenda Escolar, portanto, é de grande importância e precisa ser mantido, apesar da sobrecarga que representa para a administraçáo das escolas e do sistema de ensino. Por isso mesmo, a crise de financiamento do programa teve repercussóes sociais muito profundas.

Mas a crise contribuiu, também, para expor problemas estruturais do próprio programa e constituiu ocasião para rediscutir os seus objetivos e a sua eficácia.

O primeiro problema diz respeito à extensão que o programa deve assumir. Mesmo que recursos regulares e relativamente abundantes venham a ser restabelecidos, há de se perguntar sobre a necessidade e o interesse em colocar, como objetivo, o fornecimento de merenda a todas as crianças. A Constituição não o exige, pois apenas fala em programas suplementares.

Atender a todas as crianças do Brasil, 200 dias por ano, custaria cerca de 2 bilhóes de dólares. A decisáo do Governo de atuar desta forma, tomada há alguns anos, não é realista, porque são milhóes as crianças que não necessitam merenda. Sucede, porém, que, lançada a 
bandeira demagógica de fornecer merenda a todas as crianças, criam-se expectativas irrealistas, as quais originam reclamaçóes de toda ordem quando náo são satisfeitas. Os recursos liberados efetivamente têm ficado muito aquém do referido valor.

Pode-se sempre argumentar, como freqüentemente é feito, que é melhor gastar dinheiro com a alimentaçăo das crianças (mesmo que elas náo o necessitem) do que desperdiçá-lo com outras atividades muito menos nobres; $\mathrm{e}$, ainda, que os recursos seriam facilmente obtidos se se acabasse com a corrupçáo, ou se diminuísse o número de funcionários públicos ociosos, e assim por diante.

Esse tipo de argumento é basicamente equivocado, pois estabelece alternativas inteiramente abstratas, dependentes de uma evoluçáo política do país que só ocorrerá a longo prazo. O que deve ser decidido é se é melhor gastar um bilhão de dólares para dar comida a todos, inclusive aos que não necessitam, ou se não seria a melhor solução dispender parte deste dinheiro para aumentar a abrangência do atendimento às crianças realmente necessitadas, melhorando o atendimento médico, o fornecimento de material escolar, a promoçáo de atividades culturais e assim por diante.

As medidas que foram tomadas durante a crise de financiamento foram eminentemente sensatas. Consistiram em dirigir os recursos existentes para as regiōes mais pobres (Norte e Nordeste).

Há, evidentemente, alunos carentes em todos os estados da Federaçáo. Năo existem dúvidas, porém, de que, percentualmente, o número de crianças carentes matriculadas nos estabelecimentos de ensino público nas regióes mais ricas do país é menor. Além do mais, há de se convir que, nessas regióes, os governos estaduais e municipais dispōem de melhores condiçōes financeiras e econômicas para enfrentar situaçóes adversas.

Solucionado o problema emergencial, há de se preservar um critério seletivo para o programa, o que permitirá que ele se torne menor, mas muito mais eficiente e eficaz, estabelecendo áreas prioritárias dc atendimento.

O segundo problema que emerge na análise da eficiência do programa diz respeito à sua centralização. $O$ que se pergunta é se não seria mais adequado à Uniáo repassar os recursos e as responsabilidades pela merenda diretamente aos estados e municípios.

Há vantagens e desvantagens na centralização. Uma das vantagens 
reside na economia de escala que é possível desenvolver quando se centralizam as compras. Esta questáo inclui outra, que é a da oposição entre merenda formulada e alimentos frescos. A centralização envolve, se não a exclusividade, pelo menos a preponderância dos formulados. Uma refeição balanceada, com produtos frescos, adequada aos hábitos alimentares locais, certamente constituiria o ideal. Entretanto, é bem mais fácil garantir que a refeiçăo seja efetivamente balanceada utilizando os formulados, além das vantagens paralelas de facilidade de estocagem $\mathbf{e}$ preparo que podem implicar considerável redução de custos. Por outro lado, a própria concentraçáo das compras e o volume dos recursos envolvidos cria possibilidades de corrupção muito grandes, além de multiplicar os problemas da distribuição.

A descentralização completa da merenda simplificaria a administração do programa $\mathrm{e}, \mathrm{em}$ muitas regióes, constituiria certamente uma soluçấo viável. Ela teria, ainda, a vantagem de promover a aplicação local dos recursos, estimulando a economia municipal.

Todavia, a experiência revelou que a grande maioria das prefeituras dos municípios mais pobres deixa de aplicar os recursos na merenda, ocasionando danos irreparáveis e reflexo imediato no desempenho escolar, sobretudo em períodos de crise financeira ou devido a problemas políticos comuns em épocas de eleiçóes. A questão da fiscalização do uso dos recursos torna-se extremamente complexa e quase inviável. Por outro lado, como é comum o atraso no repasse das verbas, o processo fica sujeito a descontinuidades constantes. A municipalizaçáo poderia, numa primeira fase, ser tentada em estados do Sul/Sudeste, cujos municípios estão mais aparelhados para assumir tal responsabilidade.

Em outras regióes, a estadualização da merenda poderia ser um estágio intermediário para 'se chegar, futuramente, à municipalização, mas deveria restringir-se aos estados que demonstrassem a capacidade administrativa de gerir um programa como este.

Mesmo que essa estratégia fosse adotada, deveria ser examinada a conveniência de se manter, no MEC, um programa de distribuição direta de formulados, que poderia constituir a base da merenda, a ser complementada por estados e municípios, com alimentos locais frescos. Isto garantiria um mínimo, mas permitiria uma simplificaçáo do programa, de tal sorte que o Ministério pudesse, de forma mais eficaz, assumir a responsabilidade pela merenda integral nos municípios mais pobres e mais necessitados, em funçăo de critérios objetivos como renda média per capita.

Num país com a heterogeneidade do Brasil, devem ser evitadas 
soluçóes simplificadoras que consistem em estabelecer uma única opçăo e uma única alternativa. Na situação atual, não parece sensato abdicar do potencial que a União possui para corrigir distorçóes e desigualdades regionais e locais, através de um serviço federal.

\section{O livro didático}

O significado social e os problemas do Programa do Livro Didático (e fornecimento de material escolar) são bastante semelhantes aos da merenda escolar. Sendo os recursos provenientes da mesma fonte (o Finsocial), o Programa do Livro Didático foi, entretanto, ainda mais prejudicado pela crise de financiamento, em virtude da importância central assumida pela merenda.

Náo há dúvida, entretanto, de que o fornecimento de material escolar constitui uma das medidas mais importantes para a melhoria da qualidade do ensino, pois pode suprir muitas das deficiências dos professores. Estudo recente, realizado sob o patrocínio do Banco Mundial em regióes pobres do Nordeste, demonstrou que o investimento em material didático é o que produz os melhores e mais imediatos resultados em termos de aprendizagem.

Alguma coisa tem sido efetivamente feita pelo Ministério da Educação nesse sentido. Num período de seis anos - 1986-1991 - , foram distribuídos gratuitamente aos alunos do $1^{\circ}$ grau 220 milhóes de livros, ou seja, uma média de 37 milhóes por ano. Como existem cerca de 25 milhōes de crianças neste grau de ensino, significa, idealmente, que cada um teria recebido pelo menos um livro do Ministério da Educaçăo.

Para atender às suas necessidades educacionais, os alunos deveriam ter recebido três livros. Há, portanto, um problema fundamental do livro didático no Brasil que é quantitativo: apenas um terço dos livros necessários está disponível, obrigando os responsáveis a uma verdadeira ginnistica para atender à população escolar.

Parte deste esforço consiste em fazer livros resistentes, que possam ser usados durante três anos, o que raramente se consegue. Náo só a durabilidade deles é muito pequena, como há enorme variação na indicação feita pelos professores, de um ano para outro, tornando os livros antigos inaproveitáveis. Além disso, há outros problemas: o fluxo de recursos para a compra dos livros é irregular, o que faz com que, às vezes, sejam distribuídos no fim do período letivo. No passado, até a 
distribuição dos livros era irregular, mas o problema foi solucionado encarregando-se os Correios e Telégrafos desta tarefa.

Um problema adicional rclaciona-se à escolha dos livros; contrariamente ao que se faz em alguns outros países, como o Japão, onde livros escolares sáo padronizados e existem, portanto, poucos títulos, no Brasil há milhares deles e uma forte concorrência entre as editoras. Só para dar um exemplo, o catálogo de livros da FAE de 1992 possuía 3.500 títulos.

O sistema centralizado, com poucos títulos, é típico de sistemas autoritários, mas o leque existente no Brasil não só conduz a uma fragmentação excessiva, como não tem sido capaz de garantir um mínimo de qualidade no conteúdo dos livros. O Ministério da Educaçáo náo escolhe livros-texto, mas oferece um catálogo aos estados e municípios, no qual, de modo geral, os professores escolhem democraticamente os títulos que desejam ver distribuídos aos seus alunos.

O sistema descentralizado de escolha tem a vantagem de evitar a possibilidade de corrupçáo que sempre está presente quando recursos muito vultosos dependem de decisóes dos escalóes burocráticos. Mas, nesse sistema, não há qualquer controle da qualidade dos textos oferecidos e, como muitos professores da rede são despreparados, nem sempre possuem condiçóes para fazerem uma avaliação criteriosa do conteúdo dos livros. Na prática, o que tem ocorrido é algumas poucas editoras conseguirem ver seus livros adotados, através de marketing agressivo, ou, às vezes, por razóes ideológicas náo ausentes na escolha feita pelos professores.

Por outro lado, o fato da FAE ser o principal mercado de algumas grandes editoras cria certos problemas: quando os recursos sáo liberados, as editoras recebem grandes encomendas, apesar de ficarem ociosas o resto do ano. A produçáo rápida, bem como o desejo de atender o maior número possível de alunos, afetam a qualidade. A solução, neste caso, consistiria em regularizar o fluxo de recursos para a FAE e em institucionalizar um programa de avaliaçáo do conteúdo dos livros didáticos, através de comissóes ad hoc, formadas por especialistas de competência reconhecida.

\section{Os CIACs e outras iniciativas}

Como vimos anteriormente, não há, na realidade, falta de salas de 
aula no país, apesar do problema existir em algumas regióes onde são particularmente intensos os problemas das migraçóes internas, associados à explosáo populacional dos grandes centros urbanos. Um exemplo é a Grande São Paulo, na qual há um déficit de cerca de seis mil salas de aula (apesar de existir cerca de seis mil salas ociosas no interior do Estado). Esse problema cria a necessidade de introduzir mais de três turmas por dia em cada sala, criando limitaçóes à qualidade do ensino devido à curta permanência dos alunos na escola, agravando os problemas de repetência e evasão para a populaçăo mais pobre.

O ideal, naturalmente, seria que os alunos permanecessem de seis a oito horas por dia na escola, como ocorre no exterior ou nas escolas de elite no Brasil; o Governo Collor tentou introduzir o período integral nas áreas mais carentes através dos CIACs (Centro Integrado de Atendimento à Criança). Procurou-se neles - além de uma escola - criar o espaço para educação artística, cultural, esportiva e atendimento médico-social.

O plano inicial era o de construir cinco mil CIACs até 1094, que atenderiam, no mínimo, cinco milhóes de crianças, com um nível de ensino $e$ atendimento social muito superior ao atual. $O$ plano era claramente ambicioso demais. O custo de cada CIAC, com capacidade de educar mil alunos, era de dois milhóes de dólares, de modo que o projeto inicial superava, em muito, a capacidade de investimento do Governo. Além disso, a idéia inicial era a de que o Governo Federal construísse os CIACs e os entregasse aos estados e municípios para operação, mesmo porque esta é sua responsabilidade central na área da educação. Entretanto, como o custo de operação de um CIAC é muito mais elevado do que o de uma escola comum - cerca de três vezes maior - prefeitos e governadores, percebendo o empenho do Presidente no sucesso do projeto, passaram a pressionar o Governo Federal a assumir também tais custos, o que acabaria por inviabilizar o programa, tanto do ponto de vista financeiro como administrativo.

Além disso, o programa enfrentou, desde o início, muito ceticismo e resistência, em parte justificados, devido a experiências educacionais anteriores fracassadas e ao caráter excessivamente ambicioso do projeto.

Algumas dessas críticas referiam-se à criação de uma situação de injustiça, pois o programa beneficiaria apenas parte da populaçăo, deixando a maioria em escolas tradicionais.

Na realidade, logo que o programa foi transferido para a responsa- 
bilidade do MEC (inicialmente era coordenado pelo Ministério da Saúde), ele foi adaptado para atender tambem às demais escolas, melhorando suas instalaçóes físicas com centro esportivo e outras benfeitorias. Esta ciaquizafáto das escolas comuns complementaria o trabalho do FNDE, o principal responsável pela construçáo de prédios escolares em todo o país.

Além disso, contemplou-se também ressuscitar a idéia de escolaparque, transformando o tempo integral, de obrigatório, em voluntário. As aulas seriam concentradas num único período $\mathrm{e}$ as atividades assistenciais, culturais, recreativas e de formaçăo profissional ocorreriam em outro. Desta forma seria possível duplicar o atendimento, mantendo duas turmas, pois o espaço utilizado nesses dois tipos de atividade é diverso.

O programa dos CIACs não chegou a tomar forma definitiva em virtude da mudança de governo, mas constituiu uma das poucas tentativas, em nível federal, de enfrentar com audácia o desafio de garantir a escolarizaçáo básica completa de oito séries para a populaçáo mais pobre, oferecendo às crianças melhores condiçóes de aprendizagem.

Além dos CIACs, outras tentativas têm sido feitas por diversos governadores e prefeitos para resolver os problemas da educação na sua esfera de competência. Tanto no Rio de Janeiro como em São Paulo e Minas Gerais, as secretarias de Educaçáo têm desenvolvido projetos para a melhoria do ensino fundamental. Assim também, muitas prefeituras.

Uma das iniciativas mais interessantes está em andamento na cidade de Maringá (Paraná), onde o prefeito entregou a gestão de grande parte das escolas públicas a cooperativas de pais e professores da rede pública que recebem recursos da prefeitura através de um contrato de gestão, que remunera a escola de acordo com o número de alunos que efetivamente freqüenta as aulas. Apesar da oposiçáo corporativista dos sindicatos, a experiência parece bem-sucedida, tendo reduzido dramaticamente a taxa de evasão, principal problema do ensino público no país.

Não há dúvida que uma presença cada vez mais marcante dos municípios na área de educação é a direçáo a seguir para a solução dos problemas atuais.

\section{O ensino médio}

O ensino de 20 gran

As atenções, tanto da opinião pública como da imprensa e dos 
educadores, tém estado muito mais voltadas para o ensino fundamental e o ensino superior do que para o $2^{\circ}$ grau. Ao passo que naqueles dois outros níveis propostas inovadoras vêm sendo apresentadas, o nível médio parece quase esquecido.

Entretanto, considerando a necessidade de modernização do país, o ensino médio tem um papel muito importante a desempenhar. Tanto nos países desenvolvidos como naqueles que estáo conseguindo superar rapidamente o subdesenvolvimento, afirmando-se como potências econômicas, a expansão do ensino médio foi um poderoso fator de qualificação da mão-de-obra para a realização da revolução tecnológica. Esta qualificação não significa necessariamente ensino técnico (embora este seja importante), mas processa-se também pela formaçáo geral, aprofundando o domínio da língua, da matemática e das ciências.

No caso do Brasil, onde o problema de qualificação para o trabalho é muito sério e há enorme deficiência de profissionais de nível médio, a expansáo e melhoria da qualidade do ensino do $2^{\circ}$ grau precisa ser seriamente considerada.

Tanto a legislaçáo quanto a tradição atribuem aos governos estaduais a responsabilidade para com o ensino médio. Como se vê na tabela 21 , os estados cumprem efetivamente esta atribuição, pois estáo matriculados em estabelecimentos estaduais $62,4 \%$ dos estudantes, o que representa quase $90 \%$ das matrículas no setor público. A contribuição das escolas municipais e federais é muito pequena (respectivamente $4,4 \% \mathrm{e}$ $2,8 \%$ ). O setor privado, entretanto, é bastante importante neste segmento do sistema de ensino, cabendo-lhe $30,4 \%$ das matrículas.

O contingente dos alunos é de cerca de três milhóes e meio, o que pode ser considerado muito pequeno, por representar apenas $16,7 \% \mathrm{da}$ faixa etária de 15 a 19 anos (tabela 22), em desfavorável comparação com o percentual de países desenvolvidos e em desenvolvimento: México, 55\%; Taiwan, 91\%; Coréia, 94\%; Japão, $96 \%$ (9).

Embora pequeno, esse percentual é resultado de um crescimento significativo. Há menos de 20 anos, em 1973, em todo o $2^{\circ}$ grau havia pouco mais de $\mathbf{9 0 0}$ mil alunos, o que representava menos de $8 \%$ da faixa etária considerada.

O desejável seria a aceleração desse crescimento. $O$ maior obstáculo para a expansão do ensino médio reside, entretanto, no número muito pequeno de alunos que consegue terminar o $1^{\circ}$ grau, sem o quê náo podem ingressar no nível médio. 
Tabela 21

Ensino Médio: Número de Matrículas e Porcentagens por Instâncias Administrativa

\begin{tabular}{lrr}
\hline Tipo de estabelecimento & \multicolumn{1}{c}{ № } & \multicolumn{1}{c}{$\%$} \\
\hline Federais & 97.777 & 2,81 \\
Estaduais & 2.170 .632 & 62,41 \\
Municipais & 152.981 & 4,40 \\
Total de escolas públicas & 2.421 .390 & 69,60 \\
Particulares & 1.056 .469 & 30,37 \\
Total Geral & 3.477 .850 & 100,00 \\
\hline
\end{tabular}

Fonte: MEC-SAG.

Tabela 22

Ensino Médio - Taxa de Escolarização na Faixa dos 15-19 Anos Brasil 1973-1990

\begin{tabular}{lccc}
\hline ano & $\begin{array}{c}\text { População } \\
15-19 \text { anos }\end{array}$ & $\begin{array}{c}\text { Matrícula inicial } \\
\text { ensino médio } \\
\text { faixa etária } \\
15-19 \text { anos }\end{array}$ & $\begin{array}{c}\text { Taxa de } \\
\text { escolarização } \\
15-19 \text { anos } \\
\text { ensino médio }\end{array}$ \\
\hline 1973 & 11.716 .830 & 908.489 & 7,8 \\
1974 & 11.997 .187 & 1.047 .249 & 8,7 \\
1975 & 12.000 .000 & 1.227 .017 & 10,2 \\
1976 & 12.157 .208 & 1.408 .479 & 11,6 \\
1977 & 13.362 .640 & 1.583 .366 & 11,9 \\
1978 & 12.696 .244 & 1.708 .982 & 13,5 \\
1979 & 13.042 .563 & 1.826 .345 & 14,0 \\
1980 & 13.277 .662 & 1.930 .289 & 14,5 \\
1981 & 13.613 .778 & 1.967 .350 & 14,4 \\
1982 & 13.503 .618 & 1.986 .802 & 14,7 \\
1983 & 13.633 .958 & 1.900 .500 & 13,9 \\
1984 & 13.740 .569 & 1.987 .171 & 14,5 \\
1985 & 13.869 .671 & 1.998 .212 & 14,4 \\
1986 & 14.016 .591 & 2.057 .920 & 15,2 \\
1987 & 14.083 .944 & 2.182 .866 & 15,5 \\
$1988 *$ & 14.329 .641 & 2.300 .000 & 16,0 \\
$1989 *$ & 14.572 .517 & 2.400 .000 & 16,5 \\
$1990^{*}$ & 15.000 .000 & 2.500 .000 & 16,7 \\
\hline
\end{tabular}

(*) Estimativas

Fontes: IBGE-Pesquisa Nacional por Amostra de Domicilios e MEC-SAG-CPS-CIP. 
Como mostra a tabela 23 , as mạtrículas na $1^{\text {a }}$ série do $2^{\circ}$ grau são em número superior ao de concluintes do ensino fundamental, $e$ isso consistentemente, através dos anos. Náo há, portanto, falta de vagas no ensino médio e uma expansão pode significar a criação de vagas ociosas. Mas é necessário encontrar uma justificativa para esse estranho fenômeno do aumento de matrículas na passagem de um grau para outro. A explicação é dupla. Em primeiro lugar, o $2^{\circ}$ grau absorve, além dos egressos do $1^{\circ}$ grau regular, também os concluintes do ensino supletivo. Mas o fator preponderante é, muito provavelmente, a repetição dọ fenômeno já analisado no ensino fundamental: o represamento dos alunos na série inicial pela repetência, que está associado ao abandono da escola antes da conclusão do curso.

Tabela 23

Número de Concluintes no Ensino Fundamental e Matrícula Inicial na 1ª Série do Ensino Médio Brasil 1973-1990

\begin{tabular}{ccc}
\hline Ano & $\begin{array}{c}\text { Concluintes } \\
\text { do ensino } \\
\text { fundamental }\end{array}$ & $\begin{array}{c}\text { Matrícula inicial } \\
\text { na la série do } \\
\text { ensino médio }\end{array}$ \\
\hline 1973 & 603.073 & 639.718 \\
1974 & 734.498 & 722.635 \\
1975 & 790.247 & 885.349 \\
1976 & 823.875 & 1.004 .013 \\
1977 & 837.379 & 1.065 .848 \\
1978 & 856.172 & 1.104 .481 \\
1979 & 1.007 .610 & 1.167 .823 \\
1980 & 860.471 & 1.220 .727 \\
1981 & 846.537 & 1.209 .428 \\
1982 & 890.224 & 1.233 .140 \\
1983 & 859.997 & 1.285 .693 \\
1984 & 865.131 & 1.277 .922 \\
1985 & 863.272 & 1.321 .964 \\
1986 & 906.000 & 1.328 .853 \\
1987 & 930.000 & 1.399 .426 \\
$1988^{*}$ & 940.000 & 1.500 .000 \\
$1989^{*}$ & 950.000 & 1.615 .000 \\
$1990^{*}$ & 960.000 & 1.735 .000 \\
\hline
\end{tabular}

* Estimativas

Fonte: MEC-SAG-CPS-CIP. 
O fenômeno não só existe mas está se agravando, o que é extremamente prcocupante. É isso que nos demonstra a tabela 24.

\section{Tabela 24}

Ensino Regular de $2 \circ$ Grau

Matrícula Inicial na $1^{\text {a }}$ Série, Concluintes e Taxa de Conclusão no Ensino Regular de 2\% Grau segundo a Coorte Brasil 1970-1986

\begin{tabular}{lrcc}
\hline Coorte & $\begin{array}{c}\text { Matrícula } \\
\text { Inicial na } \\
\text { la série }\end{array}$ & Concluintes & $\begin{array}{c}\text { Taxa } \\
\text { de } \\
\text { Conclusão }\end{array}$ \\
\hline $1970-1973$ & 445.773 & 329.851 & 74,0 \\
$1971-1974$ & 503.132 & 350.177 & 69,6 \\
$1972-1975$ & 580.157 & 368.479 & 63,5 \\
$1973-1976$ & 639.718 & 435.489 & 68,1 \\
$1974-1977$ & 722.639 & 434.577 & 60,1 \\
$1975-1978$ & 885.349 & 524.524 & 59,2 \\
$1976-1979$ & 1.004 .013 & 512.024 & 51,0 \\
$1977-1980$ & 1.065 .848 & 541.350 & 50,8 \\
$1978-1981$ & 1.104 .481 & 561.683 & 50,8 \\
$1979-1982$ & 1.167 .823 & 583.300 & 49,9 \\
$1980-1983$ & 1.220 .727 & 590.479 & 48,4 \\
$1981-1984$ & 1.209 .428 & 585.193 & 48,4 \\
$1982-1985$ & 1.233 .140 & 557.727 & 45,2 \\
$1983-1986$ & 1.265 .693 & 606.959 & 47,9 \\
\hline
\end{tabular}

Fonte: MEC-SAG-CPS-Coordenação de Informaçōes para o Planejamento

Como se vê nessa tabela, em 1973, de cada 100 alunos matriculados na $I^{\text {a }}$ série, 74 haviam concluído o curso três anos depois. A taxa de conclusão vai baixando consistentemente através dos anos, para atingir apenas 48 alunos - menos da metade - no grupo que ingressou em 1983 e deveria terminar o curso em 1986.

O decréscimo da taxa de conclusão indica que a expansão foi acompanhada por uma diminuiçáo da sua eficiência e assinala a existência de problemas muito sérios no $2^{\circ}$ grau.

O que parece ter ocorrido é que a expansão das matrículas impli- 
cou uma diversificação da clientela, à qual a organização tradicional dos cursos náo consegue atender. $O$ problema tem a ver com o currículo $e$ a preparaçáo dos professores.

A diversificação da clientela pode ser comprovada pelo fato de que $50 \%$ das matrículas no ensino médio são no período noturno. Isto significa dever-se a expansão verificada, em grande parte, à absorção de jovens que trabalham e, anteriormente, cstavam excluídos desse grau de ensino.

Nos países desenvolvidos, a expansão do ensino médio está associada a um enriquecimento da populaçāo, de forma a permitir a um número crescente de famílias postergar a entrada dos filhos no mercado de trabalho: o ensino médio é preponderantemente diurno e de tempo integral. Não foi isso o que ocorreu no Brasil. Mas a escola brasileira, aprisionada em normas rígidas e uniformes, não diferencia, em termos da relaçăo ensino-aprendizagem, enure jovens de classe média ou alta, que apenas estudam, $e$ os que trabalham para garantir sua subsistência $e$ estudam à noite.

O problema dessas diferenças de classe, e das condiçốes heterogêneas de aprendizado que elas implicam, não é certamente novo, nem está restrito ao $2^{\circ}$ grau, mas é particularmente grave nessa faixa etária, que é aquela na qual se dá o ingresso no mercado de trabalho formal.

No passado, tanto no Brasil como nos países avançados, o ensino médio se dividiu claramente em duas vertentes: uma, de preparação para a universidade, cujo acesso ficava praticamente restrito às classes médias e superiores; outra, profissionalizante, de caráter terminativo, que recrutava nas classes trabalhadoras e formava uma mão-de-obra mais qualificada.

No caso brasileiro, a vertente propedêutica foi claramente preponderante e, enquanto se restringia às camadas mais favorecidas, foi possível manter um ensino público de muito boa qualidade. A formaçáo propriamente técnica, por outro lado, não foi favorecida pelo setor público e jamais alcançou o nível existente nos países avançados. Voltaremos à questáo do ensino tecnológico mais adiante, mas convém assinalar que foi a iniciativa privada, através do SENAI, quem ocupou o espaço abandonado pelo setor público.

O caráter excludente de uma divisão desta natureza tem levado os países de democracia consolidada, onde as escolas são bem melhores que as nossas, a contestar tal concepção pedagógica pelo seu caráter elitista, propondo, para todo o ensino médio, uma mesma base que valoriza a 
formação geral. O ideal é oferecer a todos, simultaneamente, a oportunidade tanto para prosscguir nos estudos como para adquirir uma qualificação que lhes permita ocupar posiçóes mais vantajosas no mercado de trabalho.

No Brasil, essa mesma tendência tem preponderado há já três décadas, mas com resultados muito insatisfatórios. A experiência mais ambiciosa consistiu na reforma educacional imposta de cima para baixo através da competência normativa do Estado (como a maioria das reformas que tivemos), a qual obrigou o ensino de matérias profissionalizantes $\mathrm{em}$ todos os estabelecimentos de $2^{\circ}$ grau. Essa profissionalização obrigatória redundou num grande fracasso. A tendência oposta, que acabou dominando, foi a de fortalecer uniformemente a formaçáo científica e cultural, mas também não tem alcançado êxito.

O problema está em que não se igualam oportunidades oferecendo ủma educação uniforme a uma população escolar marcada por uma profunda desigualdade, tanto na sua formação anterior como nas condiçóes de estudo que possuem. Disso só pode resultar ou a produção de uma desigualdade no desempenho escolar ou a deterioraçáo da qualidade do ensino.

A solução para o ensino médio brasileiro deve contemplar sua diversificação para atender a uma clientela heterogênea, sem com isso reinstalar a dicotomia rígida, existente no passado, entre cursos profissionalizantes, que excluem o acesso ao ensino superior, e cursos propedêuticos, que o permitem.

A experiência brasileira mais bem-sucedida nessa direçăo foi o antigo curso normal, que conseguiu, através de várias gerações, formar um corpo de professores primários bastante adequado às necessidades do ensino no país. $O$ antigo curso normal conseguiu, efetivamente, integrar (e náo simplesmente justapor) a formação profissional a uma boa formaçáo geral, e nisso residiu, certamente, muito do seu sucesso. As sucessivas reformas educacionais o descaracterizaram porque quebraram esta integração.

É verdade que o sucesso dessa experiência não se deveu apenas ao seu conteúdo pedagógico. De um lado, o prestígio e os salários razoáveis dos professores permitiram o recrutamento de candidatos com um bom desempenho escolar anterior. De outro, a própria restriçăo do acesso à escola, na época, excluía a parcela mais pobre da populaçáo, aquela que exigia uma adaptação cultural maior ao ambiente escolar, tornando a tarefa do professor mais fácil e a pedagogia existente mais adequada. 
Nenhuma dessas condições existe hoje. $O$ desprestígio da profissão, associada aos baixos salários, faz com que o recrutamento se dê exatamente entre a populaçáo mais pobre e de menor aproveitamento escolar. $O$ resultado disso é revelado pelas pesquisas sobre desempenho escolar realizadas pela Fundação Carlos Chagas, as quais demonstram que o pior desempenho ocorre justamente nos cursos de formação do magistério.

Ante a situação do ensino médio, há que se perguntar o que a Uniáo pode fazer e tem feito a este respeito.

Devemos reconhecer que a União tem feito muito pouco. Sua atuaçáo direta está praticamente restrita ao ensino tecnológico, do qual trataremos mais adiante. Nos demais segmentos, há uma grave omissão.

A razão principal dessa restrição ou omissão reside na ausência de recursos. Como mostramos anteriormente, as verbas do MEC, que têm como fonte os $18 \%$ dos recursos do Tesouro alocadas à educação, são quase inteiramente dispendidas com o ensino superior, área na qual, pela legislação atual, o Ministério deve atuar preferencialmente. Por outro lado, o ensino médio não conta com fontes de recursos adicionais, como é o caso do ensino básico, para o qual existe o FNDE. Dessa forma, tanto a funçăo supletiva da União como a redistributiva ficam seriamente prejudicadas, dificultando sua capacidade de promover uma renovação nesse nível de ensino.

Exemplo disso foram as dificuldades encontradas em 1991 e 1992 para aprovar um projeto das universidades do Rio de Janeiro, associadas na tarefa de promover a qualificaçáo dos professores do $2^{\circ}$ grau, uma vez que os recursos existentes no MEC estavam legalmente restritos à aplicação no $1^{\circ}$ grau.

Uma ação puramente normativa, através do Conselho Federal de Educação ou de projeto de lei, seria inteiramente ineficaz se, paralelamente, não fossem garantidos recursos para a reciclagem dos professores e sua permanência na rede de ensino. Desta forma, enquanto não se alterar a estrutura orçamentária do $\mathrm{MEC}$, a responsabilidade para com - $2^{\circ}$ grau fica, de fato, inteiramente a cargo dos estados.

A atuação da União no ensino regular de $2^{\circ}$ grau pode se dar indiretamente, através de outra vertente: a formaçáo de professores, nas universidades, para o ensino de nível médio, assim como para as quatro últimas séries do $1^{\circ}$ grau.

As licenciaturas têm-se revelado extremamente insatisfatórias para 
a formaçáo de professores. Há, certamente, a necessidade de uma ampla revisāo desta área, abandonando o modelo de justapor matérias pedagógicas às de formaçáo na área específica de conhecimento, sem entrosamento e sem conexáo entre as duas partes.

A SENESu chegou a iniciar gestōes junto às universidades federais, no sentido de promover uma revisao das licenciaturas. A descontinuidade administrativa não permitiu, entretanto, 0 desenvolvimento deste projeto. Mas trata-se, sem dúvida, de uma área prioritária para a política educacional do país.

Para resolver tal problema, há que se promover uma açáo conjunta da União, das universidades e das Secretarias Estaduais de Educaçáo. Tanto quanto no ensino de $1^{\circ}$ grau, o caminho consiste em oferecer aos futuros professores melhor preparo, criando oportunidades para o treinamento em serviço; recompensando diferencialmente, através de melhores salários, os docentes que apresentem maior qualificaçáo e melhor desempenho; $e$ aumentando a autonomia $e$ a responsabilidade das escolas.

\section{$A$ educafão tecnológica}

Nos países desenvolvidos, as escolas técnicas de nível médio ou superior constituem uma parte muito importante do sistema de ensino e desempenham um papel cssencial na formação dos jovens sem vocação acadêmica e na preparaçăo de mão-de-obra qualificada para o mercado de trabalho.

No Brasil, o ensino técnico tem sido implantado com muita dificuldade e constitui uma parte ínfima do sistema público. Contribui para isso, certamente, o fato de que a escolarização de nível médio esteve tradicionalmente restrita, no país, aos jovens de classes médias e superiores, sem tradição familiar de trabalho manual.

A implantaçáo do ensino tecnológico através do recrutamento nas classes trabalhadoras deve-se à iniciativa do setor empresarial, o qual criou o SENAI e o SENAC. Essas instituiçōes fornecem formaçăo técnica gratuita a jovens trabalhadores, em diferentes níveis e tipos de cursos.

Foi em virtude da deficiência do setor público na área de formação técnica que o Ministério da Educaçáo, cumprindo sua funçáo supletiva, passou a atuar nesse campo do ensino, através de duas iniciativas. 
A primeira consistiu na construção de escolas técnicas e agrotécnicas de $1^{\circ}$ grau. O programa foi formulado em termos de colaboração entre a Uniáo e os municípios; cabe ao $\mathrm{MEC}$ a construção e o equipamento das escolas, competindo aos municípios que as recebem mantêlas e geri-las. A concepçáo é correta, pois seria certamente impossível para o MEC administrar diretamente uma rede de escolas que se pretendia muito ampla.

Os resultados do programa, entretanto, não têm sido inteiramente satisfatórios, e as pressóes políticas têm contribuído muito para deformar os resultados.

A construção dessas escolas tem sido, de fato, extremamente influenciada por pressóes políticas locais, cuja força nem sempre coincide com uma avaliaçáo objetiva da oportunidade e necessidade da iniciativa. Prefeitos que conseguem, através de apoio de deputados, a aprovação para uma dessas construçóes, são muitas vezes substituídos antes do término das obras - e novos prefcitos raramente se interessam pelo sucesso de um empreendimento iniciado por um rival político. Além do mais, municípios pobres lutam pela obtençáo dessas escolas, vistas como uma benesse da Uniáo, sem levarem em conta os custos posteriores de sua manutenção, muitas vezes demasiado elevados para os recursos das prefeituras. O levantamento parcial da situação desses estabelecimentos escolarcs, iniciado pelo MEC, revelou uma alta incidência de escolas deterioradas ou abandonadas, o que representa um enorme desperdício dos escassos recursos da educaçắo.

A segunda iniciativa do $\mathrm{MEC}$ consistiu na criação e manutenção de uma rede própria de escolas técnicas federais, que inclui hoje 19 estabelecimentos técnicos e 37 agrotécnicos, em nível de $2^{\circ}$ grau. Além disso, há cinco Centros Federais de Educação Tecnológica, os quais, além da formação em nível médio, oferecem também cursos em nível superior. Estas escolas técnicas federais foram inspiradas pelo sucesso das Fachhochschulen alemãs e constituem, aparentemente, uma iniciativa bem-sucedida, a julgar pela sua excelente aceitação e pela pressão que $o$ Ministério recebe no sentido de ampliar a rede.

A qualidade do ensino oferecido nas escolas técnicas federais de $2^{\circ}$ grau tende a ser melhor que no comum da rede pública. $O$ mesmo estudo da Fundação Carlos Chagas, referido anteriormente, indicou que os melhores índices de desempenho escolar eram obtidos por alunos dessas escolas. Apesar disso, há problemas que precisam ser seriamente considerados.

O primeiro deles reside no custo muito elevado das escolas técni- 
cas federais. O sistema todo atende a cerca de 100 mil alunos, emprega cerca de 10 mil professores e consome rccursos da ordem de $230 \mathrm{mi}$ lhóes de dólares por ano, ou seja, $5,4 \%$ do orçamento do MEC. O custo-aluno é portanto de cerca de 2.300 dólares por ano, constituindo quase 10 vezes mais do que é gasto na rede regular de ensino público.

Parte da elevação do custo deve-se ao fato de que a construção e a instalação de escolas técnicas, especialmente em termos de equipamento, são muito mais caras do que a das escolas comuns. Mas, no caso da rede federal, a razão principal para o custo tão elevado reside no tamanho excessivo do corpo docente em relação ao discente. A média de alunos por professor é de cerca de 10 , isto é, inferior ao de muitas universidades que aliam ensino e pesquisa.

Em virtude do custo é difícil contemplar uma ampliação de tal iniciativa, e o tamanho reduzido da rede impede que ela desempenhe um papel significativo na formação de máo-de-obra para o conjunto do mercado de trabalho brasilciro. Os 100 mil alunos das escolas federais representam muito pouco quando comparados aos do SENAI, o qual atendeu, em 1989, nas 270 unidades de ensino que mantém, cerca de 1 milhão e 200 mil jovens, isto é, 12 vezes mais. O SENAC, por outro lado, com 332 unidades escolares em 1604 municípios do país, matriculou no mesmo ano 1 milhão e $\mathbf{2 4 0}$ mil alunos, utilizando apenas $\mathbf{8 . 2 3 7}$ professores, instrutores e agentes de formaçáo profissional.

Outro problema das escolas técnicas e agrotécnicas constitui um verdadeiro paradoxo e diz respeito à clientela e ao aproveitamento dos egressos. Pelo fato mesmo de receberem recursos relativamente mais elevados do que as outras escolas públicas de $2^{\circ}$ grau e ministrarem ensino em tempo integral, as escolas técnicas são capazes de oferecer melhor formação aos estudantes. Suas vagas, por isso mesmo, são disputadas por jovens provenientes das classes médias, sem tradição de trabalho manual, muitos dos quais se dirigem posteriormente às universidades e não ao mercado de trabalho. As escolas técnicas transformam-se assim em instituiçóes de elite e encontramos situaçóes como a de escolas agrotécnicas, instaladas na zona rural, que precisam de ônibus para transportar os alunos, residentes na zona urbana, cujas famílias não trabalham na agricultura.

É verdade que, mesmo assim, as escolas técnicas prestam um bom serviço educacional. Mas dificilmente pode-se dizer que cumpram de maneira eficaz o seu objetivo central, que é o de suprir o mercado de trabalho com técnicos de nível médio.

Finalmente, há de se considerar os problemas de ordem adminis- 
trativa, que dizem respeito à cnorme dificuldade em gerir, de Brasília, um sistema de escolas cujo sucesso em formar mão-de-obra tecnicamente qualificada depende da agilidade de decisóes e do entrosamento com o setor produtivo local.

Este problema, que já é grave no caso das universidades, fica multiplicado no caso das escolas técnicas, as quais não são autarquias nem fundaçóes, como aquelas, mas estão incluídas na administração direta. Dessa forma, contrataçóes, dispensas, compra de material, manutenção de equipamentos, convênios com empresas, tudo precisa ser decidido em Brasília. A manutenção dessa estrutura rígida e do centralismo das decisóes é, sem dúvida, um fator que, impedindo qualquer agilidade por parte da direção da escola, contribui para a elevação dos custos e diminui a eficiência do sistema. Sem a agilidade necessária e com uma localizaçáo que obedece antes a interesses políticos que às necessidades e possibilidades do mercado de trabalho, as escolas técnicas dificilmente mostramse capazes de utilizar eficazmente, através do mecanismo de estágios, a capacidade instalada do parque industrial para o treinamento dos alunos. Muitas delas são inteiramente dependentes de oficinas próprias, as quais se tornam rapidamente obsoletas.

Sáo fatores como esses, geralmente ignorados pelos legisladores e pelas organizaçóes corporativas, que aconselham uma estadualizaçáo da rede de escolas técnicas, com o repasse correspondente de recursos. A municipalização não seria aconselhável, a não ser $\mathrm{em}$ casos especiais, $\mathrm{em}$ virtude da experiência em grande parte negativa das escolas agrícolas de Io grau.

O problema do ensino técnico no país é extremamente importante e a União deve certamente colaborar para resolvê-lo. Mas é inteiramente irrealista esperar que ela possa fazê-lo sozinha, através de escolas federais. Com os recursos atuais do Ministério, já é difícil manter a rede existente. Não tem sido esta, entretanto, a compreensão do Congresso, que anualmente introduz emendas no orçamento para o início da construçăo de novas escolas técnicas federais, sem prever recursos para sua conclusão e, muito menos, para sua manutençáo. Já estão aprovadas mais de $\mathbf{2 0 0}$ novas escolas, parte das quais com construção iniciada mas sem qualquer previsão de recursos para a continuidade das obras. $O$ mais grave, entretanto, é que, concluídas essas escolas, o Ministério certamente não poderá mantê-las ou administrá-las.

\section{As escolas particulares: \\ o problema das mensalidades escolares}

A atuação do Ministério da Educação tem se concentrado no sis- 
tema público, que atende à grande maioria da população. Além disso, o controle e avaliaçáo do ensino privado de $1^{\circ}$ e $2^{\circ}$ graus é de responsabilidade dos estados. A ação da União neste sistema privado é puramente normativa e sua influência exercida, em grande parte, através da fixação do currículo mínimo. A fiscalização, propriamente, cabe aos estados.

A competência do Ministério da Educação deveria restringir-se a essa normatização e à avaliaçáo. Mas em nenhuma destas duas áreas a açáo do MEC tem sido solicitada, e sim em outra: a do controle do valor das mensalidades escolares.

A Constituição estabelece que o ensino é livre à iniciativa privada, cabendo ao Poder Público autorizar e avaliar sua qualidade, funçóes estas que cabem, em última análise, ao Ministério da Educação. A rigor, portanto, não cabe ao Estado envolver-se na questáo do custo do ensino privado nem fixar mensalidades escolares, a não ser no âmbito da política econômica do Governo.

Entretanto, com a recessão econômica e as dificuldades encontradas por setores da classe média, usuários das escolas particulares, para fazer face ao aumento do valor das mensalidades, criou-se enorme pressão por parte dos pais para que o Governo controlasse o preço cobrado por esses estabelecimentos. Inúmeras tentativas têm sido feitas, através de leis e decretos, para fixar as mensalidades e determinar as formas de reajuste. $O$ sucesso desses esforços não tem sido grande e, por isso, sucedem-se protestos dos alunos, dos pais e dos donos de escola. Mais recentemente, vêm ocorrendo manifestaçóes públicas e até ocupação de escolas.

Na verdade, a forma correta de controle dos preços das escolas particulares pelo Poder Público deveria ser indireta, através da melhoria da rede pública. Desse modo, se o ensino particular se torna demasiado caro, os pais transferem os filhos para as escolas estaduais ou municipais. As escolas particulares, ameaçadas de perder a clientela, são forçadas a manter as mensalidades em níveis compatíveis com a renda da população que atendem.

No caso brasileiro, o problema reside numa questão de qualidade. As famílias de escolaridade mais alta querem oferecer aos seus filhos uma educação melhor do que aquela disponível nas escolas públicas. Mas gerir uma escola privada é uma atividade econômica em que as mensalidades devem cobrir o custo do serviço oferecido e, dentro de certos limites, o custo será tanto mais alto quanto melhor o serviço. Os pais procuram colocar os filhos nas melhores escolas privadas porque 
acreditam que é nelas que eles terāo a melhor educação. Mas, paradoxalmente, desejam que, através de uma regulamentaçăo do Poder Público, elas ofereçam os seus serviços por um preço muito reduzido.

A única soluçáo que satisfaria a todos, donos de escolas e pais, acabando com a verdadeira guerra que se instalou, seria a de que o Estado subsidiasse a matrícula dessas crianças. Mas isso significaria uma verdadeira privatização dos recursos públicos destinados à educação, que náo sáo suficientes hoje nem para melhorar substancialmente a qualidade da rede pública. Beneficiando apenas alguns, tais medidas apenas aumentam a iniquiidade do sistema, que é o que se está procurando combater.

Uma política educacional adequada deve ter claramente como prioridade a solução definitiva para esse problema: a melhoria da escola pública. Uma atuaçáo fiscalizadora dos pais mais instruídos nas escolas mantidas pelo Poder Público, assim como sua colaboração no melhoramento das condiçóes materiais e da programação cultural desses estabelecimentos, contribuiria enormemente para a melhoria da qualidade do cnsino.

Há, entretanto, de se reconhecer um outro lado da questão, que reside no fato de ser impossível solucionar o problema dessa forma a curto prazo. Tem-se argumentado, e é verdade, que a educaçáo náo constitui um bem de mercado igual a qualquer outro. Como a saúde, trata-se de um serviço essencial. Por isso, ele precisa ser autorizado pelo Estado, tendo o caráter de uma concessão pública. É isso que, na opinião dos pais, justificaria a fixaçáo do valor das mensalidades pelo Poder Público. A atuaçāo do Estado deve ocorrer para coibir abusos, mas isso não pode significar fixação de preços, o que só acarretaria a diminuição da qualidade desejada de início.

Há, portanto, de se encontrar uma soluçáo equilibrada e de bom senso, que tenha claramente caráter provisório, pois seria de todo indesejável a permanente interferência do Estado na fixaçăo de preços.

As leis atuais (de nos 8170 e 8178 , de 1991) são inadequadas. Elas estabelecem o seguinte procedimento para o cálculo de mensalidades: no início do ano, 45 dias antes das aulas começarem, as escolas fixam livremente seus preços; pais ou alunos têm 10 dias para recorrer; negocia-se e, se não há acordo, a questão vai à Justiça. Em agosto, as escolas podem repassar $30 \%$ da inflaçáo acumulada (medida pelo INPC). Os aumentos salariais dos professores são repassados em $70 \%$ às mensalidades. 
O resultado é que os alunos começam o segundo semestre com grandes aumentos (de $70 \%$ a $100 \%$ ). Não tendo recorrido no período estabelecido pela lei nem previsto o acúmulo da inflaçáo, os pais clamam pela intervenção do Estado. Os donos de escola, por outro lado, reclamam dos prejuízos que tiveram durante o período em que náo puderam efetuar reajustes.

A solução para tal problema está na utilização de reajustes mensais baseados em indicadores da FIPE, da FGV ou outros. A regularidade dos aumentos mensais com base em um indicador pré-fixado, apesar de elevado, garantiu às escolas que o utilizaram (ilegalmente) poucas reclamaçōes.

Reconhecendo que esta é a linha natural para evitar conflitos, o Governo enviou, no começo do ano passado, novo projeto de lei que, cssencialmente, legaliza tal procedimento, mas não permite liberdade completa para fixação de mensalidades. A proposta exige que as escolas, ao fixarem livremente suas mensalidades (de acordo com a qualidade dos serviços que oferecem), forneçam uma planilha explicitando os custos que estas mensalidades cobrirấo. Daí para frente, os reajustes serão automáticos, de acordo com a evolução dos itens que constam da planilha: salários, despesas com luz, água, limpeza etc.

Parece-nos urgente que o projeto tenha andamento. Com as taxas de inflação correntes, escolas só podem manter a qualidade dos serviços com reajustes mensais, como ocorre no resto da economia.

O projeto de lei encontra-se na Comissáo de Defesa do Consumidor e até hoje náo teve andamento, apesar de várias negociaçóes com os setores interessados. Aparcntemente, há deputados que não confiam em planilhas e desejariam maior interferência do Poder Público; por outro lado, outros, representando donos de escolas, que náo desejam ver estabelecida regra transparente alguma, que permita verificar qual sua margem de lucro.

\section{Conclusão}

A análise e discussão contidas neste trabalho levam a um conjunto de conclusóes referentes ao sistema educacional brasileiro. No que se refere à educaçáo básica, as prioridades para a ação estão bastante claras:

- diminuir a repetência, especialmente nas séries iniciais, de forma a assegurar que acesso à escola signifique, realmente, a universalizaçáo 
de uma escolarização mínima de oito séries;

- ampliar o acesso ao $2^{\circ}$ grau;

- melhorar a qualidade do ensino, de forma a fornecer à população uma formação adequada, tanto ao exercício da cidadania como à inserção no mercado de trabalho.

Para atingi-los torna-se necessária uma série de medidas que envolve:

- treinamento de professores;

- melhoria da situação salarial dos docentes, associada ao desempenho;

- assistência ao estudante, especialmente através da merenda escolar e material didático para os que deles necessitam.

O estabelecimento de prioridades, entretanto, não cria, por si só, as condições para a execução da política. Esta depende da existência de instrumentos de ação.

No que diz respeito à educaçáo, ao mesmo tempo em que se espera do Governo Federal uma açáo decisiva, que resolva todos os problemas do ensino, não se leva em devida conta que os instrumentos à disposição do Ministério são muito poucos e sua capacidade de atuação restrita, ainda mais porquanto a manutenção da rede escolar é de responsabilidade dos estados e municípios, os quais possuem grande autonomia de ação.

O Ministério possui, é verdade, ampla competência normativa. Seria possível, portanto, propor uma reforma educacional através do Conselho Federal de Educação. Atuar nesse sentido, entretanto, seria persistir na ilusão técnico-burocrática (da qual partilham, aliás, muitos educadores, políticos e boa parte da população), acreditando que se possa criar uma nova realidade por Accreto. A proposta da nova Lei de Diretrizes e Base da Educação Nacional, por cxemplo, partilha dessa ilusáo, pois simplesmente decreta a obrigatoriedade de uma escolarização completa e de boa qualidade para todos, prevendo ainda o atendimento integral na pré-escola, a atenção especial ao estudante que trabalha e aos excepcionais, além de remuneração condigna para os professores, sem estabelecer prioridades e sem levar em conta os recursos disponíveis.

Ninguém, $\mathrm{cm}$ sã consciência, seria contra este ideal. Mas a idéia de que os problemas reais seráo resolvidos pela Lei tem como contrapartida a ilusão de que, daí em diante, a tarefa da sociedade organizada consiste simplesmente em cobrar do Executivo que execute o que foi decidido, como se o Governo tivesse uma varinha de condáo que tornasse isso possível. 
O que deve ser feito, na órbita de ação do Ministério, é tentar dirigir de forma coerente os recursos de que dispóe, privilegiando as regióes mais pobres $\mathrm{e}$ utilizando-os como apoio às iniciativas estaduais e municipais que estejam claramente orientadas no sentido de atender às prioridades estabelecidas, com racionalização dos gastos e melhoria do atendimento à população escolar; alternativamente, o Ministério pode estabelecer essa racionalizaçáo e melhoria do atendimento como précondiçáo para a concessáo de recursos federais.

Uma política educacional eficaz consiste, basicamente, num esforço de consistência capaz de superar a tendência à fragmentaçáo das iniciativas em açóes tópicas e isoladas. Essa tendência à fragmentação, deriva, de um lado, da estrutura do sistema administrativo, o qual configura os instrumentos de ação através de programas independentes e autônomos e de rubricas orçamentárias estanques: construção de escolas, auxílio para treinamento de professores, merenda escolar, livro didático, TV Educativa. De outro lado, decorre do caráter particularista das reivindicaçôes, as quais não se orientam no sentido de exigir prioridades claras e critérios transparentes de distribuiçáa de recursos - ao contrário, consistem em pressóes para obtençáo de atendimento privilegiado a um ou outro Estado, município ou escola, ou ainda a clientelas políticas específicas (como ocorre no caso do Crédito Educativo e no valor das mensalidades escolares).

Por isso mesmo, a constituição de uma vontade política capaz de promover a solução dos problemas educacionais não pode ser confundida com a simples exigência de que o Executivo atenda indiscriminadamente ao conjunto heterogêneo das demandas.

\section{Notas}

1 Este percentual inclui os que estavam freqüentando a cscola e os que a haviam freqüentado, embora a tivessem abandonado.

2 Năo estão computadas as crianças que já haviam frequentado a escola mas abandonaramna antes dos 14 anos. Também excluído pequeno percentual de crianças com 7 anos que ainda freqüentavam a pré-escola.

3 Inclui os estabelecimentos municipais não gratuitos e que são mantidos como instituiçōes privadas comunitárias.

4 Como se trata de outra fonte (UNESCO), não há completa compatibilidade com os dados do MEC que utilizamos nas figuras anteriores.

5 Dados estimados. Não incluem as seguintes Unidades da Federaçăo: Acre, Rondônia, Paraná, Santa Catarina, Bahia e Pará. 
6 Dados estimados. Não incluem as seguintes Unidades da Fcderação: Acre, Rondônia, Paraná, Santa Catarina, Bahia e l'ará.

7 A diferença na soma deve-se à inclusão das fraçōes omitidas na linha.

8 Conforme análise de Sérgio Costa Ribeiro, (Ribeiro Sérgio Costa, A pedagogia da repetência. Estudos Avanfratos v. 12, n.5, 1991).

9 Fonte: Dahlman \& Frischtak, 1990.

Neste trabalho, o autor contou com as contribuiçōes de técnicos e funcionários do MEC, que prepararam muitos dos subsídios aqui uilizados, de assessores especiais, como o professor Décio Leal de Zagottis e a professora Elisa Wolynec, que traballharam em projetos especiais, e, particularmente, dos Secretários Nacionais, que atuaram mais diretamente com ele: o professor Antônio de Souza Teixeira Júnior (Secretário Executivo), o professor Paulo Elpídio de Meneses (Secretário Nacional de Educaçăo Básica e Secretário Executivo do FNDE), o professor Nagib Kalil (Secretário de Educação Tecnológica) e a professora Eunice Ribeiro Durham (Secretária Nacional de Educação Superior e Presidente da CAPES).

\title{
Resumo
}

Um panorama detalhado da educação no Brasil, exaninando a atividade do Poder Público, analtảbetismo, ensino básico, evasão e repetência, livro didático, ensino médio, entre outros aspectos da questão. Não é possível resolver o problema da pobreza apenas abrindo escolas. Mais da metade dos recursos do Ministério da Educação é aplicada no ensino superior, o que contraria a Constituição Federal, que dá prioridade ao combate ao analfabetismo e ao ensino fundamental. As prioridades do sistema educacional devem ser: diminuir a repetência nas escolas, ampliar o acesso ao segundo grau e melhorar a qualidade do ensino. Para ranto é preciso treinar professores, melhorar seus salários em função do desempenho e prestar assistência ao estudante com merenda escolar e material didático. A administração páblica deve usar melhor os recursos disponíveis, privilegiando as regiốes mais pobres e dando apoio as estados e municípios.

\begin{abstract}
A detailed over view of Brazilian Education, examining the Public Power activity, illiteracy, elementary education, evasion, failure, didatic books, high education, among other aspects of this matter. It is not possible to solve the poverty problem by creating new schools. More than half of the Ministry of Education resources is used in college and high level education, contrary to the Federal Constitution, which gives priority to the elementary school and the elimination of illiteracy. The priorities of the educational systems should be: reduce failure, extend the access to high school and improve the quality. In view of that it's necessary to train teachers, increase their salaries and give assistance to the students, providing snacks and books. The public administration must apply the resources in the pooer regions, giving support to the states and counties.
\end{abstract}

Josć Goldemberg, físico, foi reitor da USP, secretário nacional de Ciência e Tecnologia e ministro da Educação. É professor visitante do Programa Educação Para a Cidadania do Instituto de Estudos Avançados (IEA) da USP.

Palestra feita pelo autor em 3 de junho de 1993 no IEA-USP. 